\title{
Death Duty: Kill To Live
}

\section{Dr/ Iman Mahmoud Abd El-Tawab}

A Lecturer Of English Literature

Department Of English

Faculty Of Arts

University Of Fayoum 


\section{Death Duty : Kill To Live}

There are many concepts and various shapes for violence. Many researchers dealt and studied this subject from many sides and different point of views. If we took violence from the side of human beings, there are many kinds and shapes. But I stopped before a very sever kind of violence; that is the violence of woman against woman.

There is no gene for violence. Violence is a learned behavior, and it is often leamed in the home or the community from parents, family members, or friends. Children are more aggressive and grow up more likely to become involved in violence-either as a victimizer or as a victim-if they witness violent acts. Additionally, rates of violence vary in all groups, but are highest among males.

Nothing can set the regal character in a more contemptible point of view, than the various crimes that have elevated men to the supreme dignity. Vile intrigues, un natural crimes, and every vice that degrades our nature, have been the steps to this distinguished eminence; yet millions of men have supinely allowed the nerveless limbs of the posterity of such rapacious prowlers to rest quietly on their ensanguined thrones.

Violence can take many forms. In its classic form, it involves the use of physical force -- beating or torturing prisoners of war, raping women in the enemy camp, and, of course, the bombing and shooting that has made warfare so tragic since the dawn of the industrial age. Some observers claim that violence exists whenever force is used or threatened. For space reasons, this essay is kimited to physical and political violence.

\section{Measuring your effectiveness}

Measurement allows you to determine to what degree your efforts have succeeded, and suggests how you might modify your responses if they are not producing the intended results. You should take measures of your problem before you implement responses, to determine how serious the problem is, and after you implement them, to determine whether they have been effective. (For more detailed guidance on measuring effectiveness, see the companion guide to this series, Assessing Responses to Problems: An Introductory. Guide for Police ProblemSolvers.)

Impact measures gauge the degree to which you reduced the harms caused by the problem. Process measures gauge the degree to which you implemented responses as planned. A good assessment employs both impact and process measures.

Our analysis of our local problem should give us a better understanding of the patterns of domestic violence cases and calls in our jurisdiction. Once we have analyzed our local problem or important aspects of it and established a baseline for measuring effectiveness, we should consider possible responses to address the problem.

These strategies are drawn from a variety of sources, including descriptive materials, research studies, and police reports. It is critical that you tailor responses based on reliable analysis. In most cases, an effective strategy will involve implementing several different responses. Law enforcement responses alone are seldom effective in reducing or solving the problem. Do not limit ourselves to 
what police can do: carefully consider others in your community who , he implement more effective responses. ap ity th out the following research I'll try to

eal famous lights upon the shape of violence or

[" 1 try to shehind this violence.

the reasons to investigate and ask what

violence. Whether Education the reasons and the power force for this If the culturef lack of learning, origin, or economic circumstances. If the culture of individual himself one of these causerible and famous accident (Raiah for Man!

(Raiah and Skenah) which were happened in Alexandria 1920, made the public opinion shaking, asking, and searching for the deep and real reasons behind these cruel accidents. These brutal truth had been completed by two sisters and with the help of others aroused my curiosity to read about this statement in different sources with multi points of view.

Also, I watched all dramatic works which manipulated these crimes. So, I found myself tracing the deep and real reasons which forces two sisters to kill 17 (seventeen) female in the same Cruel way.

Were these two sisters' criminals by their innate behaviors? or acquired those bad qualities? Were they affected by economic circumstances or social circumstances and police state? Were they suffered from neglecting their emotions their inner feelings as women and lack of love, sentiments, special care from men?

Before and after every thing they were far from God, So, consequently the absence of faith and virtue. I found my self imagine that they were applied The Verse of Holy Qur'an:

"O You who believe! Fear Allah and keep your duty to him. And let every soul look to what he has sent forth for the morrow, and fear Allah. Verily Allah is well acquainted with what you do "

Women might as well never have been borm, unless it were necessary that we should be created to enable man to acquire the noble privilege of reason, the power of discerning good from evil, whilst we lie down in the dust from whence we were taken, never to rise again. It would be an endless task to trace the variety of mean nesses, cares, and sorrows, into which women are plunged by the prevailing opinion, that they were created rather to feel than reason, and that all the power they obtain must be obtained by their charms and weakness.

Novels, music, poetry, and gallantry, all tend to make women the creatures of sensation, and their character is thus formed in the mould of folly during the time they are acquiring accomplishments, the only improvement they are excited, by their station in society, to acquire. This overstretched sensibility naturally relaxes the other powers of the mind. and prevents intellect from attaining that sovereignty which it ought to attain to render a rational creature useful to others, and content with its own station; for the exercise of the understanding, as life advances, is the only method pointed out by nature to calm the passions.

The Inheritance and Social bringing up: 
All what I know from my readings and watching the dramatic works that "Raiah and Skenah" were two daughters for a father with a bad fame, he had a bad behavior. His abject poverty and bad economic circumstances led him stealing till he feit ill and still suffered from sickness and poverty till he died.

Their family (Raiah and Skenah) was a symbol of corruption. There was a wife who is the mother and a son. That mother agreed to eat and live in unmoral way without any kind of objection or refusal. She didn't give any kind of advice to her husband or even her son to work legally and eams his money in an hogo the sake of helping his father and his two sisters.

Raiah and Skenah were two sisters hadn't been brought up and directed to know the value of honor, morals and virtue. Their brother, who didn't find the good example from his father or even his mother to advice to live in a correct way and legal way.

Economic circumstances: Through out this era Egypt were suffered from colonials and English evildoers that led to decreasing the standard of living, bad conditions, and the poverty which wrapping up all circumstances around all Egyptians.

Those invaders inter new bad behaviors and unmoral way of life. These bad and refusal behaviors like drinking and using drugs. Also, exercising restitute, all these new and bad behaviors far from the kindness and piety of Egyptians, these actions happened through the absence of morals and fionest and doing all immoral to live.

A woman who has lost her honor imagines that she cannot fall lower, and as for recovering her former station, it is impossible; no exertion can wash this stain away. Losing thus every spur, and having no other means of support, prostitution becomes her only refuge, and the character is quickly depraved by circumstances over which the poor wretch has little power, unless she possesses an uncommon portion of sense and loftiness of spirit. Necessity never makes prostitution the business of men's lives; though numberless are the women who are thus rendered systematically vicious. This, however, arises in a great degree from the state of idleness in which women are educated, who are always taught to look up to man for a maintenance, and to consider their persons as the proper return for his exertions to support them. Merefricious airs, and the whole science of wantonness, have then a more powerful stimulus than either appetite or vanity; and this remark gives force to the prevailing opinion, that with chastity all is lost that is respect table in woman. Her character depends on the observance of one virtue, though the only passion fostered in her heart is love. Nay, the honor of a woman is not made even to depend on her will.

Most of the evils of life arise from a desire of present enjoyment that outruns itself. The obedience required of women in the marriage state comes under this description; the mind, naturally weakened by depending on authority, never exerts its own powers, and the obedient wife is thus rendered a weak indolent mother. A future state of existence is scarcely taken into the reckoning when only negative virtues are cultivated. For, in treating of morals, particularly when women are alluded to, writers have too often considered virtue in a very limited sense, and made the foundation of it solely worldly utility; nay, a still more fragile base has been given to this stupendous fabric, and the wayward fluctuating feelings of men have been made the standard of virtue. Yes, virtue as well as religion has been objected to the decisions of taste.

Love, considered as an animal appetite, cannot long feed on itself without expiring. And this extinction in its own flame may be termed the violent death of 


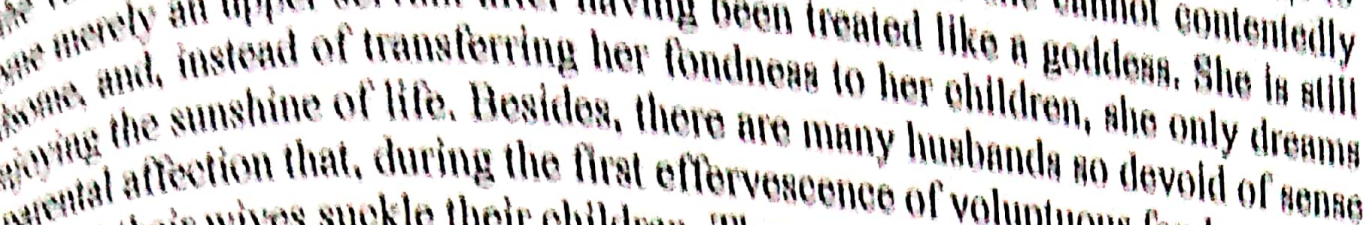

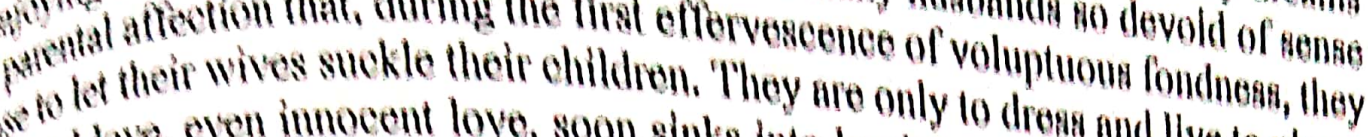

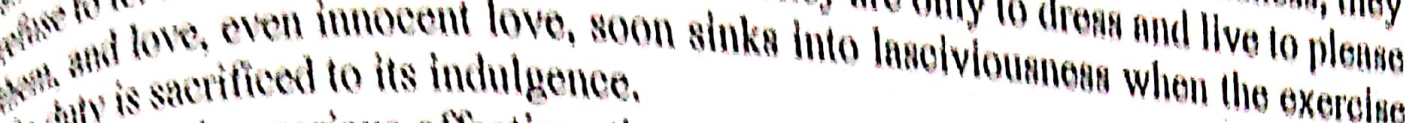
as and distip is a serions affection: the mont tist en principle, and comented by time. 'The very reverse may bon, beenuse if is areat degree, love and triendship cannot subsist in the same be ande of love, In "avired by different objects they ivenken or destroy ench other, num; even when sust can only be felt in succession. The vain fents and fond jenlous the same with fan the thame of love, when judiciously or arffully temsies, the winds intumpatible with the tender confidence and sincere respect of friencered, are both Women have seldom sufficient serious employment of hendship. pumd of little cares, or vain pursuits frittering away all so silence their feelings; a they become naturally only objects of sense. In short, the whole tenor of female dication (the education of society) tends to render the best disposed romantic and inconstant; and the remainder vain and mean. In the present state of society this evil can scarcely be remedied, I am afraid, in the slightest degrec; should a more laudable ambition ever gain ground they may be brought nearer to nature and reason, and become more virtuous and useful as they grow more respectable?

\section{Psychological Circumstances:}

Under those bad circumstances and the suffering from the lack of care, bad economic state; there was no time for love, any kind of Psychological care (paternity, maternity) care. Those two sisters didn't have luck to enjoy the care of their father in spite of his staying beside them didn't feel trust or safety.

In spite of the fact that there was the father with all its human meanings, also the mother and brother as a body only moral way. Raiah transferring these feelings of neglecting and hatred to her daughter.

Always the sea is the special romantic motive for every beautiful done. Usually with turbulent waves, solitary trees or flowers on bare cliffs or sandy beaches in the outer most fringe of the sherries.

But : for Raiah and Skenah the situation is different they became more vulgar, aggressive and butyl. Emotions died and sensations becaine very solid and unbreakable. Even the young child who is Raiah's daughter.

Necessity has been proverbially termed the mother of invention; the aphorism may be extended to virtue. It is an acquirement, and an acquirement to which pleasure must be sacrificed; and who sacrifices pleasure when it is the pursuit of knowledge mind has not been opened and strengthened people have the cares of life to struggle goaded on by necessity? Happy is it when pering a prey to enervating vices, merely with, for these struggles prevent hirth men and women be placed in a torrid zone, with from idleness. But if from their birth directly upon them, how can they sufficiently the meridian sun of pleasure darting direc 


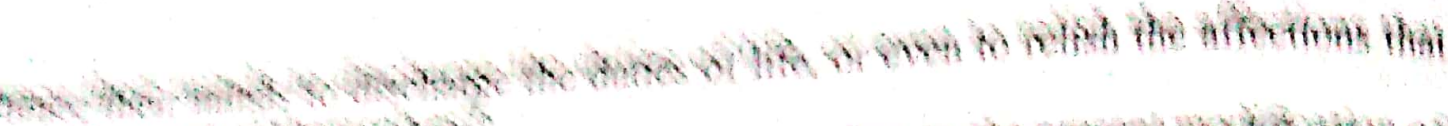

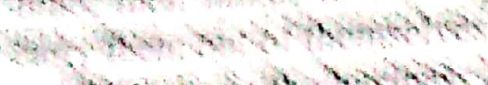

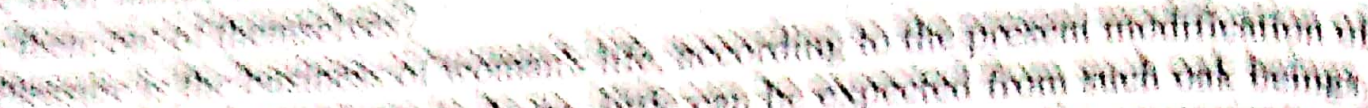

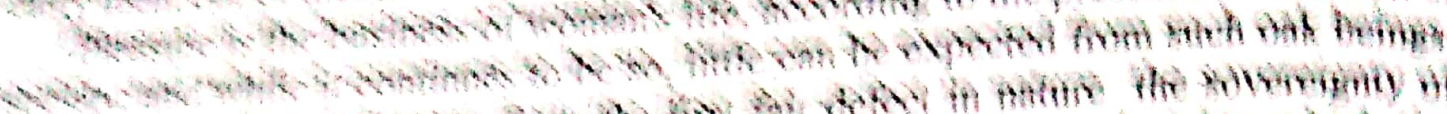
The

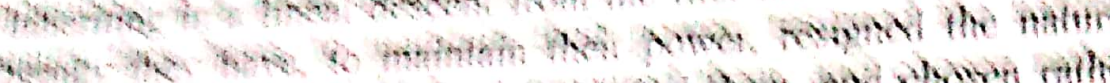

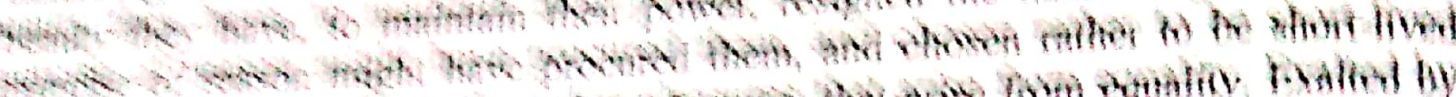

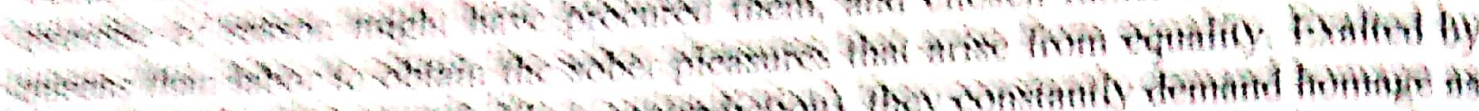

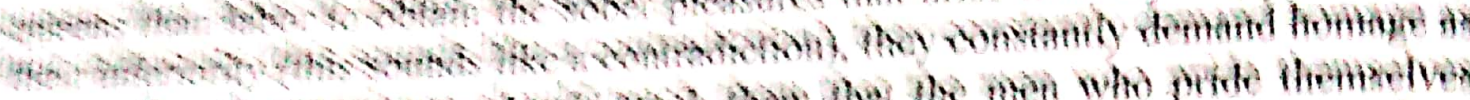

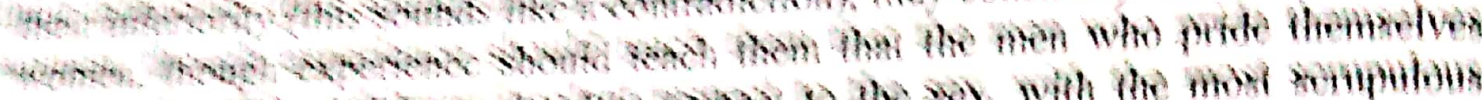

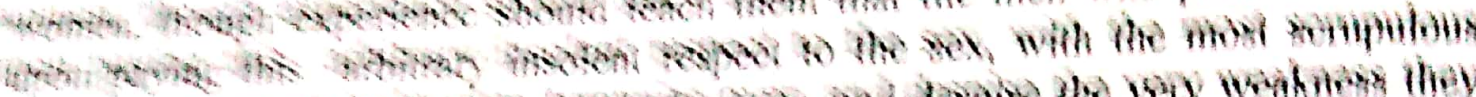

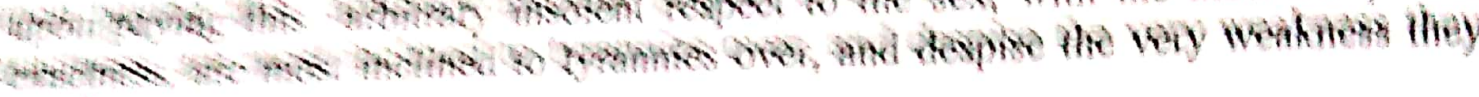

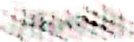

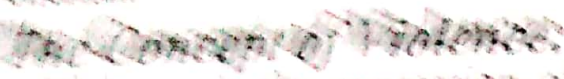

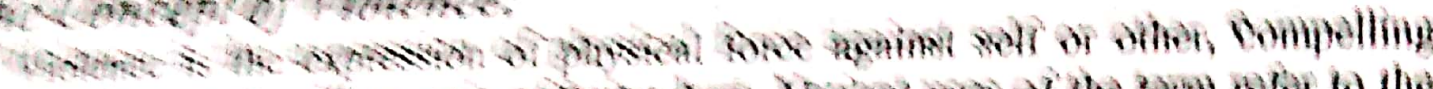

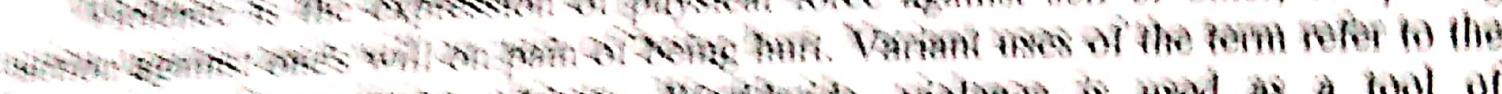

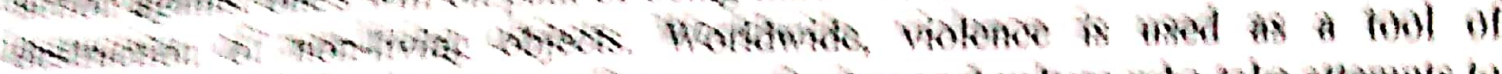

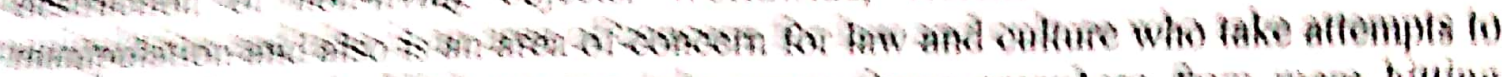

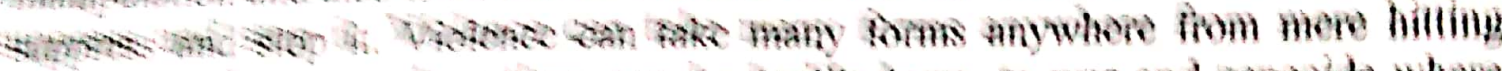

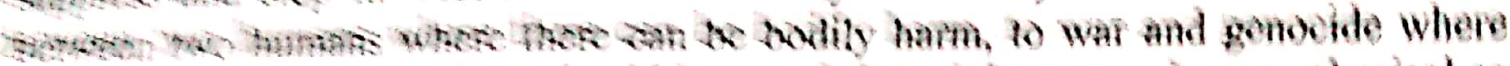

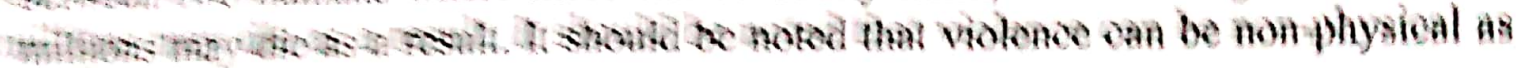
sates

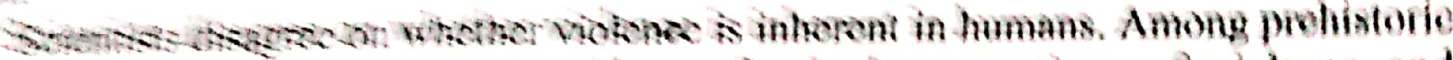

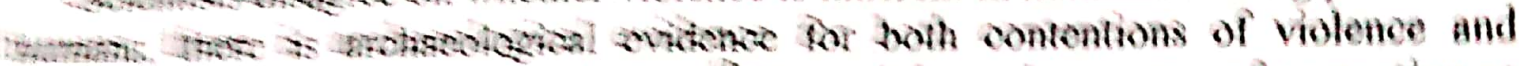

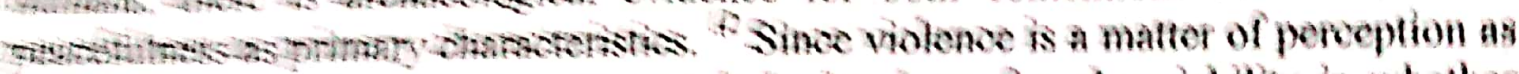

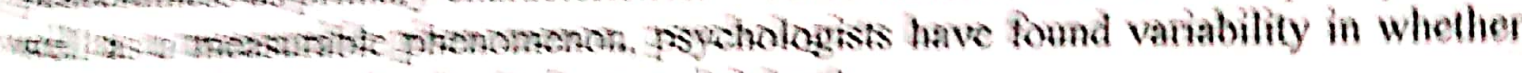

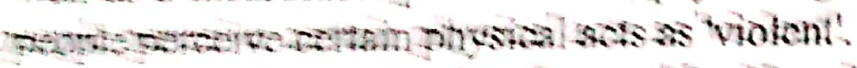

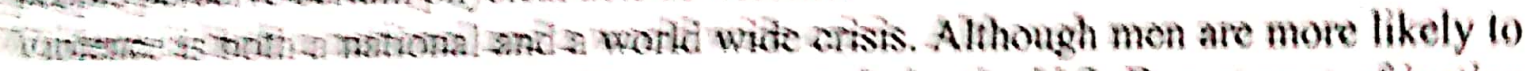

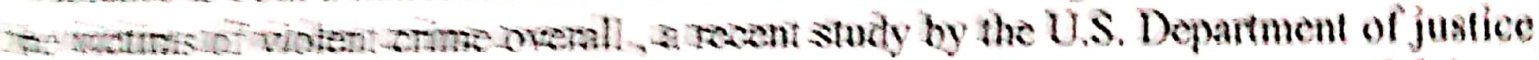

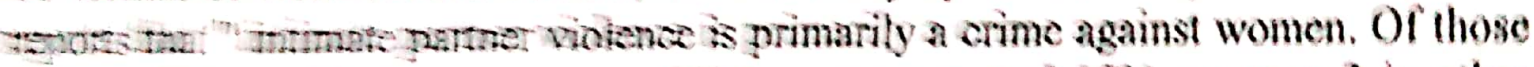
watmoxe by and intmate parmer. $85 \%$ are women and $15 \%$ are men 2 in other

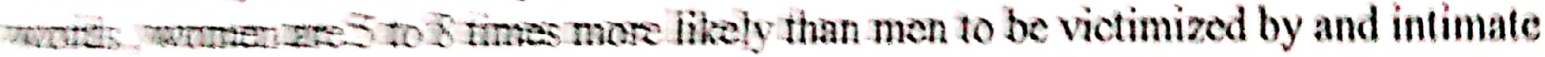

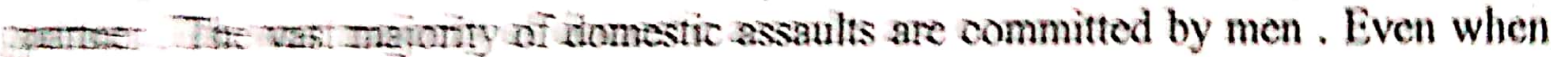

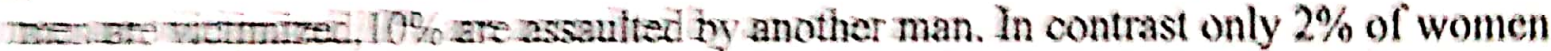
m.ucuas wormuzar are assalted by another woman.

lefereveso tess bikely to sall the nolice, even when there is injury, because, like wane they shante atout discicsing family violence. But for many men, the seme as componter by the shame of not being able to keep their wives under armo. fimone thrs grom, a "Teal man "would be able to keep her under control , luraene the poirce tend to share fhese same traditional gender role expectations. Trustades a In tegel and regulatory presumption that the offender is a man . As a IEsit te poirce are rehorant to arrest women for domestic assault. Women know Its Ine. Is trey lnow they are likely to be able to get away with it. As in the case

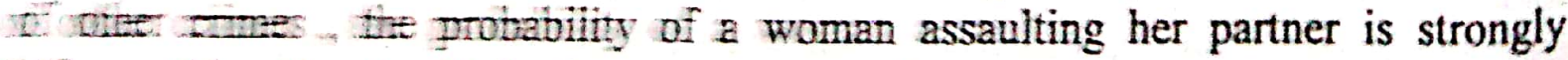

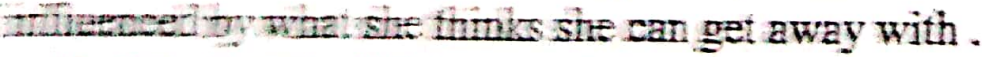

Scmosoys Max Weber stated fhat state power is the monopoly on the legitimate see th mussea Jores on e specific teritory. Law enforcement is the main means of 

no grous of people, usually under the auspices of government. War is

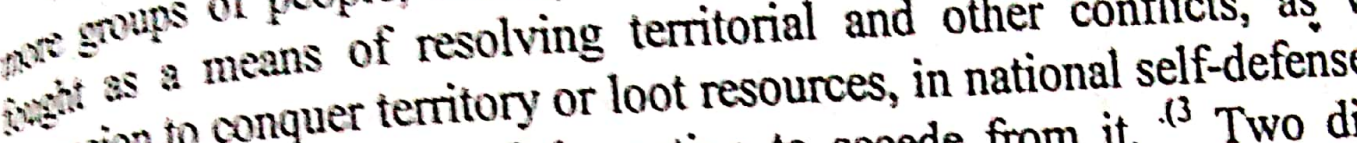

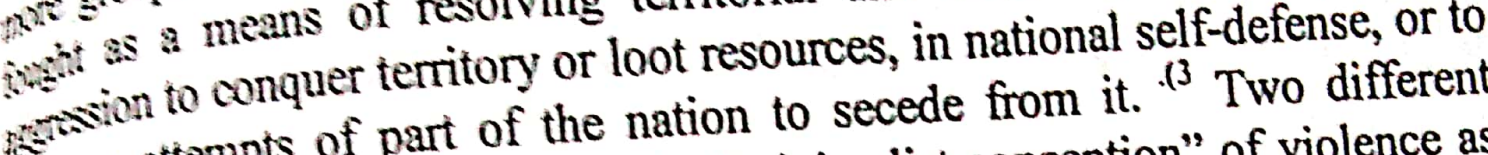
anden concepts of violence, one the "minimalist conceptice, the other the n. intentional act of excessive or destructive fights. Supporters of wannehensive conception" which includes violate that requires the state and its cpitalism are wary of a wide dofill all needs denied by structural violence. wolent enforcement agencies to fulf However, unlike those critics whenty enforced state laws intervening in markets which cause many of the problems anti-capitalists

atribute to structural violence. ${ }^{15}$.

Throughout history, most religions and inding individual violence and organizing preached that humans are capable of ellme Gandhi himself once wrote: "A society societies through purely nonviolent mo mo pomplete non-violence would be the purest anarichy." 16 Modern political ideologies which espouse similar views include pacifist varieties of voluntarism, mutualism, anarchism and libertarianism.

Many people, undoubtedly, in several respects obtain a better reputation than, strictly speaking, they deserve; for unremitting industry will mostly reach its goal in all races. They who only strive for this paltry prize, like the Pharisees, who prayed at the comers of streets, to be seen of men, verily obtain the rat is naturally reflected by heart of man cannot be read by man! Still the fair fame his steps arignt, regardless of good actions, when the man is only employed to direct his sure. the lookers-on, is, in general, not only and Prevention (CDC) defines violence as

The Centers for Disease means", which includes assault, as well as "legal "Injury inflicted by deharm".7. The World Health Organization "WHO" in its first intervention, and sert Report on Violence and Health defined violence as "the intentional use of physical force or power, threatened or actual, against oneself, another person or against a group or community, that either results in or has a high likelihood of resulting in injury, death, psychological harm, male development or deprivation." 18 
violence as "avoidable insult to basic human needs": survival, well being, identity, and freedom. This form or social institution kills people slowly

given social structure from meeting their basic needs. ${ }^{(9}$

Violence is integrated into sporting events. This was very prevalent in during the Olympic games where Wrestling and Boxing was an entertaining sport, many people would fight to the death in these spectacles. An even more well known and notorious example is in Rome where Gladiators would fight animals and other Gladiators until soncone was killed in the process, also in theatre a scene that called for a person to be killed in a violent manner, they would indeed kill an actor or a step-in. In Asia, martial arts became both a sport and a way of life for followers. Currently, Boxing, Professional Wrestling. Various Martial Arts and Mixed Martial 4 Arts are a set of violent sports that have become forms of entertainment worldwide. Government censorship has sometimes addressed violence in media, violence in games hardens children to unethical acts. ${ }^{110}$

\section{Historical examples of violence}

Acts of violence are commonly found in historical record. The following is an incomplete list of some of the more large-scale examples of violence in history. women who are bearing the brunt of financial stress. When asked about the recent financial crisis, almost half of Americans say that they are increasingly stressed about their ability to provide for their family's basic needs. Eight out of 10 say that the conomy is a significant cause of stress.

Women are most likely to report stress related to the economic climate. Compared with men, more women say they are stressed about money. Women of the Boomer generation (aged 44 to 62) and Matures (aged 63+) are most likely to report the economy as a significant stressor, while women in general rank financial worries above personal health. Female Boomers report increases in stress associated with their job stability and health problems affecting their families. Mature women are reporting dramatic increases in stress associated with health problems affecting their families. ${ }^{412}$ More people reported physical and emotional symptoms due to stress than they did in 2007 , and nearly half (47 percent) of adults reported that their stress has increased in the past year. More people report fatigue (53 percent compared to 51 percent ${ }^{113}$ in 2007), feelings of irritability or anger (60 percent compared to 50 percent in 2007) and lying awake at night (52 percent compared to 48 percent in 2007 ) as a result of stress, in addition to other symptoms including lack of interest or motivation, fecling depressed or sad, headaches and muscular tension. Women were more likely than men to report physical symptoms of stress like fatigue (57 percent compared to 49 percent), irritability (65 percent compared to 55 percent), headaches (56 percent compared to 36 percent) and feeling depressed or sad (56 percent compared to 39 percent).

Almost half of Americans (48 percent) reported overeating or eating unhealthy foods to manage stress, while one in four (39 percent) skipped a meal in the last month because of stress. Women were more likely than men to report unhealthy versus 11 percent), or napping (43 versus 32 percent). Almost one-fifth of Americans report drinking alcohol to manage their stress (18 percent), and 16 percent report smoking. " 14 "With the deteriorating economy dominating the headlines, it's easy to 


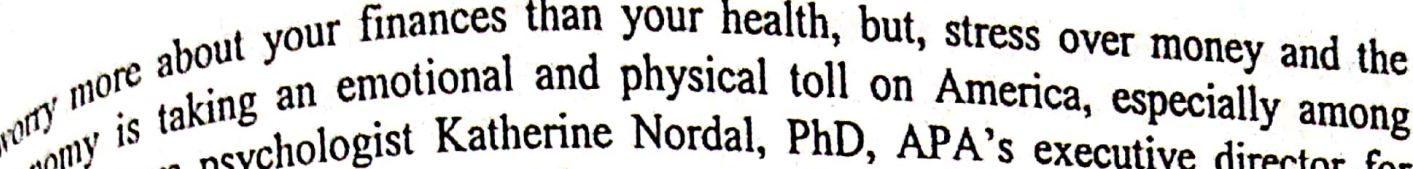
$0^{0.10^{10}}$ " says psychologist Katherine Nordal, PhD, APA's executive director for $10^{\text {mele }}$ " mal practice. "Many say they are handling their stress well. Yet, people

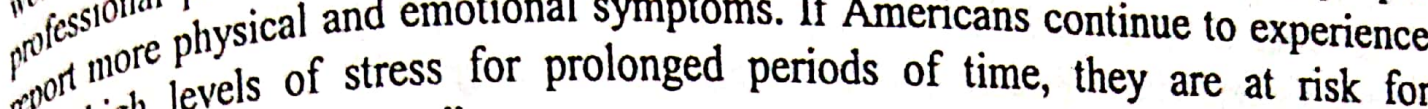

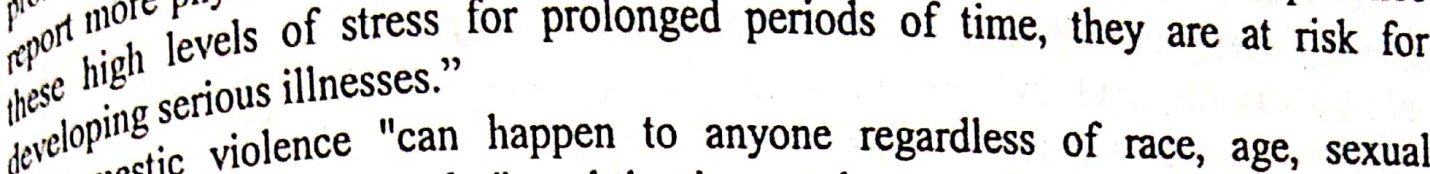

Domestic violence "can happen to anyone regardless of race, age, sexual jerentation, religion, or gender", and that it can take many forms, including physical abuse, sexual abuse, emotional, economic, and psychological abuse.

Domestic violence occurs in all cultures; people of all races, ethnicities, religions, sexes and classes can be perpetrators of domestic violence. Domestic violence is perpetrated by both men and women. ${ }^{\text {(15 }}$

Domestic violence has many forms, including physical violence, sexual abuse, emotional abuse, intimidation, economic deprivation, and threats of violence. Violence can be criminal and includes physical assault (hitting, pushing, shoving, etc.), sexual abuse (unwanted or forced sexual activity), and stalking. Although emotional, psychological and financial abuse are not criminal behaviors in some legal systems, they are forms of abuse and can lead to criminal violence. There are a number of dimensions including:

- Mode: physical, psychological, sexual and/or social.

- Frequency: on/off, occasional and chronic.

- Severity: in terms of both psychological or physical harm and the need for treatment.

- Transitory or permanent injury: mild, moderate, severe and up to homicide. ${ }^{.16}$

An important component of domestic violence, often ignored is the realm of passive abuse, leading to violence. ${ }^{(17}$ Passive abuse is covert, subtle and veiled. This includes victimization, ambiguity, neglect, spiritual and intellectual abuse. ${ }^{.18}$

Popular emphasis has tended to be on women as the victims of domestic violence. In a special report on violence related injuries by the US Department of justice (in August 1997) hospital emergency room visits pertaining to domestic violence indicated that physically abused men represent just under one-sixth of the total patients admitted to hospital reporting domestic violence as the cause of their injuries (see table 7 of this report). The report highlights that significantly more men than women did not disclose the identity of their attacker. The term "intimate partner violence" (IPV) is often used synonymously. Family violence is a broader definition, often used to include child abuse, elder abuse, and other violent acts between family members. ${ }^{(19}$ Wife abuse, wife beating, and battering are terms sometimes used, though with acknowledgment that many are not actually married to the abuser, but rather co-habiting or other arrangements. In more recent years, 'battering' or 'battered wife' has become less acceptable terminology, since abuse can take other forms than physical abuse and males are often victims of violence as well. Other forms of abuse may be constantly occurring, while physical abuse happens occasionally. These other forms of abuse have potential to lead to mental illness, self-harm, and even attempts at suicide. ${ }^{.20}$

Domestic violence can take the form of physical violence, including direct physical violence ranging from unwanted physical contact to rape and murder. 
Indirect plysical violence may include destruction of objects, striking or throwing bjects near the victim, or harm to pets. In ade including verbal threats of physical abuse oflen includes mental or emotional including children, ranging from explicit,

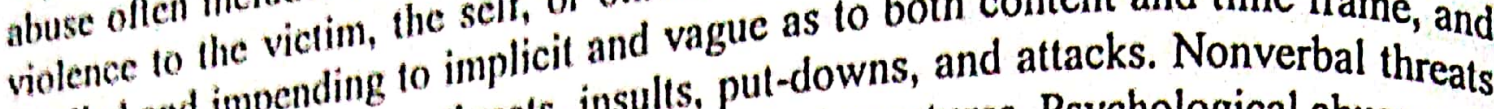
detailed and impending including threats, insults, put-downs, and body postures. Psychological abuse may verbal violence, indes, facial expressions, and, such as controlling the victim's money also involve cconomic and/or social conting the victim from seeing friends and and other economic resources, pretim's social relationships, and isolating the victim relatives, actively sabola

Physical violence is the intentional use of physical force with the potential for causing injury, harm, disability, or death, for example, hitting, shoving, biting, restraint, kicking, or use of a weapon.

\section{Sexual violence}

Sexual violence is divided into three categories

1. use of physical force to compel a person to engage in a sexual act against his or her will, whether or not the act is completed;

2. attempted or completed sex act involving a person who is unable to understand the nature or condition of the act, unable to decline participation, or unable to communicate unwillingness to engage in the sexual act, e.g., because of underage immaturity, illness, disability, or the influence of alcohol or other drugs, or because of intimidation or pressure; and

3. abusive sexual contact. ${ }^{.23}$

Men, in general, seem to employ their reason to justify prejudices, which they have imbibed, they can scarcely trace how, rather than to root them out. The mind must be strong that resolutely forms its own principles; for a kind of intellectual cowardice prevails which makes many men shrink from the task, or only do it by halves. Yet the imperfect conclusions thus drawn, are frequently very plausible, because they are built on partial experience, on just, though narrow, views.

\section{Emotional abuse}

For what purpose were the passions implanted? That man by struggling with them might attain a degree of knowledge denied to the brutes; whispers Experience. Consequently the perfection of our nature and capability of happiness, must be estimated by the degree of reason, virtue, and knowledge, that distinguish the individual, and direct the laws which bind society: and that from the exercise of reason, knowledge and virtue naturally flow, is equally undeniable, if mankind be viewed collectively.

Emotional abuse (also called psychological abuse or mental abuse) can include humiliating the victim privately or publicly, controlling what the victim can and cannot do, withholding information from the victim, deliberately doing something to make the victim feel diminished or embarrassed, isolating the victim from friends and family, implicitly blackmailing the victim by harming others when the victim expresses independence or happiness, or denying the victim access to money or other basic resources and necessities. 
Women who are being emotionally abused often feel as if they do not own
welves; rather, they may feel that their significant other has nealy them. Women undergoing emotional abuse often suffer from nearly total control them at increased risk for suicide, exting disorders, and drug ansion, which ghuse. patterns 0 ily in front of other people. This probe undermining of perceived com. Typical espectin society (including among males them can be extended due to a widence, pelief in in some way less mates themselves) that men who a widely held sobused aring help. ${ }^{25}$

\section{Violence against men}

While much attention has been focused on domestic violence against women, men's rights activists argue that domestic violence against men is a social problem

Indeed the word masculine is only a bugbear; there is little reason to ferr that women will acquire too much courage or fortitude, for their apparent inferiority with respect to bodily strength must render them in some degree dependent on men in the various relations of life; but why should it be increased by prejudices that give a sex to virtue, and confound simple truths with sensual reveries?

Women are, in fact, so much degraded by mistaken notions of female excellence, that I do not mean to add a paradox when I assert that this artificial weakness produces a propensity to tyrannies, and gives birth to cunning, the natural opponent of strength, which leads them to play off those contemptible infantine airs that undermine esteem even whilst they excite desire. Let men become more chaste and modest, and if women do not grow wiser in the same ratio, it will be clear that they have weaker under standings. It seems scarcely necessary to say that I now speak of the sex in general. Many individuals have more sense than their male relatives; and, as nothing preponderate ate where there is a constant struggle ${ }_{0}$ for an equilibrium without it has naturally more gravity, some women govern their husbands without degrading themselves, because intellect will always govern.

\section{Violence against children}

Takes Three Shapes:Child abuse, Child welfare, and Child sexual abuse.

\section{Theories :}

There are many different theories as to the causes of domestic violence. These include psychological theories that consider personality traits and mental characteristics of the offender, as well as social theories which consider external factors in the offender's environment, such as family structure, stress, social learning. As with many phenomena regarding human experience, no single approach appears to cover all cases.

Psychological:

Psychological theories focus on personality traits and mental characteristics of the offender. Personality traits include sudden bursts of anger, poor impulse control, and poor self esteem. Various theories suggest that psy a child leads some people to be disorders are factors, and Studies have found high incidence of psychopathic among more violent abusers $^{.26}$ 
Women who are most dependent on the spouse for economic well being. [clarification needed] Having children to at all the more difficult for to help them copendency financial burden and hewer options and few means that they lir spouse's behavior.

Couples that share power equally experience lower incidence of conflict, and when conflict does arise, are less likely to resort to violent to abuse. ${ }^{(28}$. desires control and power in the relationship, the threats, intimidation, emotional abuse, economic

This may include coercion the situation and blaming the spouse, using children abuse, isolation, make them away), and behaving as "master of the castle. ${ }^{(29}$ Social stress (threatening to take the ased when a person is living in a family situation, with

Stress may be incesial stresses, due to inadequate finances or other such increased pressures. Socter further increase tensions. ${ }^{130}$ Violence is not always caused problems in a family me one way that some (but not all) people respond to stress. ${ }^{31}$ by stress, but maples in poverty may be more likely to experience domestic violence, due to increased stress and conflicts about finances and other aspects. ${ }^{132}$ Some speculate that poverty may hinder a man's ability to live up to his idea of "successful manhood", thus he fears losing honor and respect. Theory suggests that when he is unable to economically support his wife, and maintain control, he may turn to misogyny, substance abuse, and crime as ways to express masculin

Whether they have acquired any virtues in exchange for innocence, equivalent to the misery produced by the vices that have been plastered over unsightly ignorance, and the freedom which has been bartered for splendid slavery. The desire of dazzling by riches, the most certain pre-eminence that man can obtain, the pleasure of commanding flattering sycophants, and many other complicated low calculations of doting self-love, have all contributed to overwhelm the mass of maikind, and make liberty a convenient handle for mock patriotism.

Social learning theory

Social learning theory suggests that people learn from observing and modeling after others' behavior. With positive reinforcement, the behavior continues. If one observes violent behavior, one is more likely to imitate it. If there are no negative consequences (e.g. victim accepts the violence, with submission), then the behavior will likely continue. Often, violence is transmitted from generation to generation in a cyclical manner. ${ }^{34}$

The most melancholy emotions of sorrowful indignation have depressed my spirits, and I have sighed when obliged to confess that either nature has made a great difference between man and man, or that the civilization which has hitherto taken place in the world has been very partial. A profound conviction that the neglected education is the grand source of the misery I deplore, and that women, in particular, are rendered weak and wretched by a variety of concurring causes, originating from one hasty conclusion. The conduct and manners of women, in fact, evidently prove that their minds are not in a healthy state; for, like the flowers which are planted in too rich a soil, strength and usefulness are sacrificed to beauty; and the flaunting leaves, after having pleased a fastidious eye, fade, disregarded on the stalk, long before the 
wen they ought to have arrived at maturity. One cause of this barren
wing atse system of education, gathered from the books fo of in this subject heen more anxious to make them

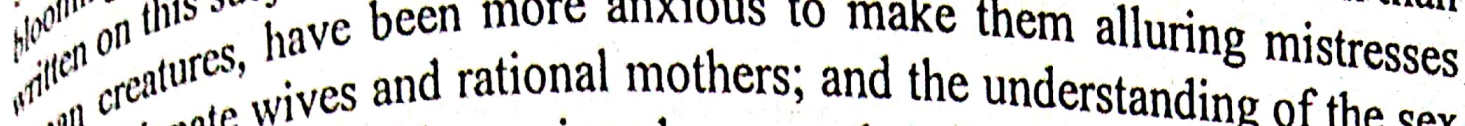
for fiectionate wives and hecious homage, that the understanding of the sex

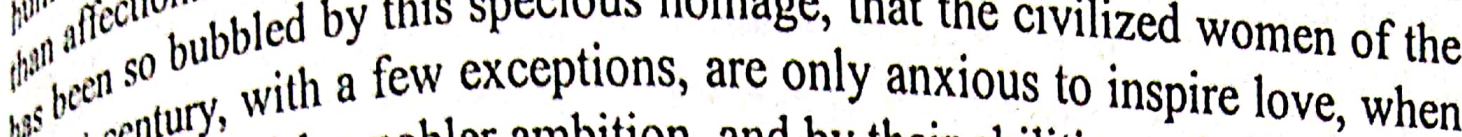
sent century, with a fewber ambition, and by their abilities and $(n)^{0}$

poiner and Control antrol, a form of bullying and social learning of abuse. Abusers' efforts to dominate thir partners have been attributed to low self-esteem or feelings of inadequacy, unresolved childhood conflicts, the stress of poverty, hostility and resentment toward women (misogyny), hostility and resentment toward men (misogyny), personality disorders, genetic tendencies and socio cultural influences, among other possible causative factors. Most authorities seem to agree that abusive personalities result from a combination of several factors, to varying degrees.

Casuals view of domestic violence is that it is a strategy to gain or maintain power and control over the victim. This view is in alignment with Bancroft's "costbenefit" theory that abuse rewards the perpetrator in ways other than, or in addition to, simply exercising power over his or her target(s). He cites evidence in support of his argument that, in most cases, abusers are quite capable of exercising control over themselves, but choose not to do so for various reasons. ${ }^{(35}$

An alternative view is that abuse arises from powerlessness and externalizing/projecting this and attempting to exercise control of the victim. It is an attempt to 'gain or maintain power and control over the victim' but even in achieving this it cannot resolve the powerlessness driving it. Such behaviors have addictive aspects leading to a cycle of abuse or violence. Mutual cycles develop when each party attempts to resolve their own powerlessness in attempting to assert control.

Critics of this model suggest that the one-sided focus is problematic as resolution can only be achieved when all participants acknowledge their responsibilities, and identify and respect mutual purpose. ${ }^{36}$ :

Other factors associated with domestic violence include heavy alcohol consumption, ${ }^{(37}$ mental illness, [citation needed] classes, various political and legal characteristics such as authoritarianism and dehumanization.

It is also important to this topic to understand the paradoxical effects of some sedative drugs. ${ }^{38}$ Serious complications can occur in conjunction with the use of sedatives creating the opposite effect as to that intended.

The paradoxical reactions may consist of depression, with or without suicidal tendencies, phobias, aggressiveness, violent behavior and symptoms sometimes misdiagnosed as psychosis. ${ }^{(39}$ The contribution of these reactions is one possible component.

Sex and Gender:

Modes of abuse are stereotyped by some to be gendered, females tending to use more psychological and men more physical forms. citation needed] The visibility of 
these differs markedly. However, experts who work with victims of domestic
that physical abuse is almost invariably preceded by violence have noted thace and hospital admission records indicate that a higher psychological abuses than males seek treatmentes and go on record as having been percentage or until more men identify a manner whereby the nature and extent of their abused by female partners, and in men will continue to be identified as the most injuries can be clinically assecal and emotional violence.

frequent perpetrators of physicance is used to describe specific violent and overtly

Frequently, domestic legal definitions will tend to take this perspective. However, abusive incidents, and lega behaviors happen within a relationship, the effects of those when violent and abusive behave overt incidents are over. Advocates and counselors will behaviors continue after these attern of behaviors, including those listed above. ${ }^{(4)}$ refer to domestic violence minds of women are enfeebled by false refinement; that the

In direct terms, that thitten by men of genius, have had the same tendency as more books of instruction, writtey are treated as a kind of subordinate beings, and not as a frivolous productions. Thecies, when im provable reason is allowed to be the dignified part of the human specis men above the brute creation, and puts a natural scepter in a distinction which raises in point of strength is, in general, inferior to the male. This is feeble hand .The fere and it does not appear to be suspended or abrogated in favor of woman. A degree of physical superiority cannot, therefore, be denied, and it is a noble prerogative! But not content with this natural pre-eminence, men endeavor to sink us still lower, merely to render us alluring objects for a moment; and women, intoxicated by the adoration which men, under the influence of their senses, pay them, do not seek to obtain a durable interest in their hearts.

Lenore Walker presented the model of a Cycle of Violence which consists of three basic phases: Honeymoon Phase Characterized by affection, apology, and apparent end of violence. During this stage the batterer feels overwhelming feelings of remorse and sadness. Some batterers walk away from the situation, while others shower their victims with love and affection.

Tension Building Phase Characterized by poor communication, unison, fear of causing outbursts. During this stage the victims try to calm the batterer down, to avoid any major violent confrontations.

Acting-out Phase Characterized by outbursts of violent, abusive incidents. During this stage the batterer attempts to dominate his/her partner(victim), with the use of domestic violence.

Although it is easy to see the outbursts of the Acting-out Phase as abuse, even the more pleasant behaviors of the Honeymoon Phase serve to perpetuate the abuse. See also the cycle of abuse article.

Many domestic violence advocates believe that the cycle of violence theory is limited and does not reflect the realities of many men and women experiencing domestic violence.

The present analyses indicate that men are among those who are likely to be on the receiving end of acts of physical aggression. The extent to which this involves mutual combat or the male equivalent to "battered women"is at present unresolved. Both situations are causes for concern. 
gitered men" those subjected to systematic and prolonged violence are likely to

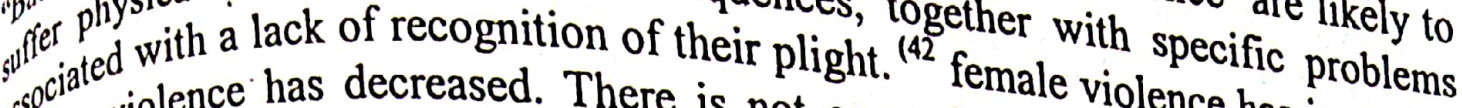
${ }^{55} 5^{0} \mathrm{~m}$ male violence has decreased. There is not one solution for every has increased as ent situation; some require incarceration of a terrorist perpetratory domestically felt with through court-mandated treatment, still others may bener, others can be deal py. Men are more violent inside and outside of the home than women. ${ }^{(43}$
A problem in conducting studies that seek to describe is the amount of silence, fear and shame that results from abunce in terms of gender relationships. Another is that abusive patterns can tend to seem within families and have lived in them for a length of time. Similarly, subtle forms of transparent even as they set the stage for further abuse sems of abuse can be quite inconsistent definition of what domestic violence is seeming normål. Finally, difficult to reach when compiling the available studies. ${ }^{(44}$ Brners in both heterosexuave been arrested and convicted of assaulting their have been men being arrested for asexual relationships. The bulk of these arrests reciprocal violence, frequently for assaulting women. However, in the case of how many instances of domestic ve male perpetrator is arrested. ${ }^{(45}$ Determining Male domestic violence victims violence actually involve male victims is difficult. ${ }^{46}$ Another study has det help for a number of reasons. aggression against men. ${ }^{(47}$

Murders of female intimate partners by men have dropiped, but not nearly as dramatically. Men kill their female intimate partners at about four times the rate that women kill their male intimate partners. Research by Jacquelyn Campbell, PhD RN FAAN has found that at least two thirds of women killed by their intimate partners were battered by those men prior to the murder. She also found that when males are killed by female intimates, the women in those relationships had been abused by their male partner about $75 \%$ of the time. See battered person syndrome and battered woman defense. There are a relationship between the availability of domestic violence services, improved laws and enforcement regarding domestic violence and increased access to divorce, and higher earnings for women with declines in intimate partner homicide ${ }^{(48}$ However, both men and women are far less likely to be abused when married to each other. The bulk of injuries from domestic violence involves cohabitation or the distresses of relationship break-ups.

Gender roles and expectations can and do play a role in abusive situations, and exploring these roles and expectations can be helpful in addressing abusive situations, as do factors like race, class, religion, sexuality and philosophy. None of these factors cause one to abuse or another to be abused. ${ }^{(49}$

Domestic violence also occurs in same-sex relationships. In an effort to be more inclusive, many organizations have made an effort to use gender-neutral terms when referring to perpetrator ship and victim hood.

Historically domestic violence has been seen as a family issue and little interest has been directed at violence in same-sex relationships. It has mot been until recently, has been directed at violement has brought the issues of gay and lesbian people into
as the gay rights movem
public attention, when research has been started to conduct on same-sex relationships. 


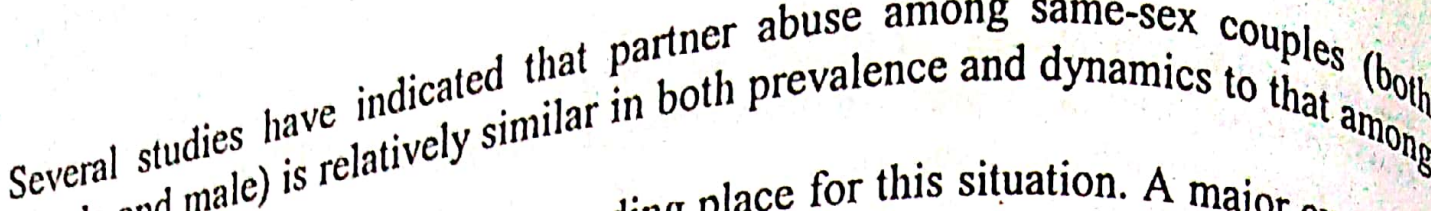
female and ma couples. The home is the arent or other family member abused is more likely to $\mathrm{se}_{e}$ A child who sees a polve problems and subsequection between violent behavior violence as a waydies do suggest there is a chat impulsivity, learning difficulties, and However, studies draits. Research has shown to violence. $\mathrm{IQ}$, or fearlessness can make someone preventing violenee in children who What do we know about

Psychological research has not only demonstrated that violence is learned. It has Psychological factors that put children at the grevion and intervention programs that
also identified the factimized by violence, along with the prevention work.

Aggression is often learned at an early age. In fact, according to Reason to Hope, the 1994 report by the APA Commission behavior in school how aggressive that predict from an eight-year-e and adulthood--including whether he or she will exhibit child will be in adolesial behavior. This is why prevention programs that start early in criminal and antisocia broughout adolescence have the best chance for success. childhood and contine

Ideally, the preveluce the risk of birth defects that could cause learning postnatal care can ren a child may be susceptible to violent behavior.

The prevention plan must encompass myriad components of the child is environment, including family members, teachers, peer groups, and media.

Effective violence prevention and intervention programs also share three primary characteristics:

- The programs zero in on developmental and socio cultural risk factors that often lead to violence.

- The programs use theory-based intervention strategies with proven track records.

(These measures are generally less costly and far more effective than building more jails.)

- The programs sustain their preventive approach over time.

Some children demonstrate a resiliency, almost from birth, that protects them from becoming violent or that makes them less vulnerable to the effects of violence. Psychological research suggests that resilience can also come from early experiences that counter the negative effects of violence. These experiences include: - Positive role models; exposure to a greater number of positive than negative
behaviors.

- Development of self-esteem and self-efficacy.

- Supportive relationships, including those with teachers and friends.

- Sense of hope about the future.

- Belief in oneself.

- Strong social skills. 
Good per relationships.

Areat empathy and support from the mother or mother figure.

The ability to find refuge and a sense of self-esteem in hobbies and creative

pirsuits, uşe

- happens.

vifence is most prevalent among the poor. Thus, although violence in no urban $a_{\text {sis }}$ is increasing, children in poor, unstable neighborhoods are more likely to be

$3_{5} 5^{\text {sult }}$ in ing violence on the screen has the following negative effects:

viewing It increases the viewer's fear of becoming a victim of violence, with a resultant increase in self-protective behaviors and increased mistrust of others.

- It desensitizes the viewer to violence, resulting in a calloused attitude toward violence directed at others and a decreased likelihood of taking action to help a victim of violence.

- It increases the viewer's appetite for becoming involved with violence.

- It often demonstrates how desirable commodities can be obtained through the use of aggression and violence.

- Sexual violence in $\mathrm{X}$ - and $\mathrm{R}$-rated videotapes widely available to teenagers

has also been shown to cause an increase male aggression against females.

These effects are both short term and long lasting. A longitudinal study of boys found a significant relation between exposure to TV violence at 8 years of age and antisocial acts--including serious violent criminal offenses and spouse abuse 22 years later.

\section{Where Do We Go from Here?}

The process by which violence is taught is circular: It begins in the family, expanding through the culture of the larger society in which a child grows and matures and then again is reinforced or discouraged in the family. The search for life stressors) requires a close look at institutitudes, images, and behaviors.

media programming that perpetuate violent atther or their children, when children are

When parents demean and strike ock on the playground, and when they have easy encouraged to be bullies or fight back on the violence is being taught.

access to real or toy guns and other weapre interactions with people who are different

When stereotypes and prejudice frat for violence. Glorifying.war and relishing

violence in competitive sports may ression are combined in the media, in song lyrics,

When violence and sexual and in the vernacular, the message of violence

in multimedia computer gamilt) is reinforced.

(including sexual assault) is until violence has been learned and practiced and then Rather than waiting urces to hiring policemen, building more prisons, and devoting increased re offenders to life imprisonment, it would be more effective to sentencing three-times to early violence prevention programs, particularly for young redirect the resources to early violence preventi 670 


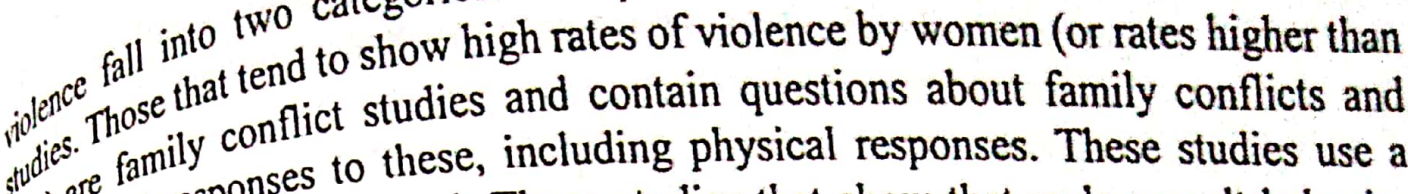
5ivin are and responses to these, including physical responses. These studies use a

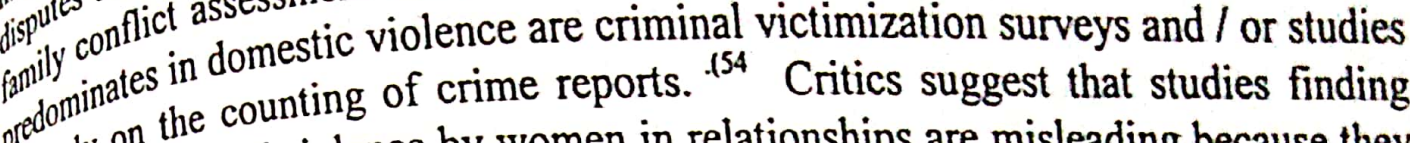
that rely on the coun violence by women in relationships are misleading because goout equal rate violence in context; in other words, there is a difference be they fail to place the vio ionce to fight back or defend oneself and someone who initien someone who uses violent. Also, the physical differences between some women an unprovoked assault. Also, the male partners may make comparisons betw kicking, punching, hitting) less meaningful, particularly because many studies show that violence by women is less likely to result in injury. Researchers agree that omen suffer the lion's share of injuries from domestic violence. ("55 Women living as partners with other women report lower rates of violence (11 percent) compared to women who live with or were married to men (30 percent). ${ }^{(56}$ About 8 percent of men living with or married to women report that they were physically abused by the women. About 15 percent of men cohabitating with men reported victimization by a male partner. These data suggest that men are engaged in more relationship violence. Harms Caused by

\section{Domestic Violence .}

Domestic violence can include murder, rape, sexual assault, robbery, and aggravated or simple assault. In addition to the physical harm victims suffer, domestic violence results in emotional harm to victims, their children, other family members, friends, neighbors, and co-workers. Victims and their children experience the brunt of the psychological trauma of abuse, suffering anxiety, stress, sleep deprivation, loss of confidence, social isolation, and fear. ${ }^{.157}$ Batterers frequently also subject their victims to harassment (such as annoying or threatening phone calls), vandalism, trespassing, stalking, criminal mischief, theft, and burglary ${ }^{188}$

Domestic violence also has economic costs. Victims may lose their jobs because of absenteeism related to the violence, and may even lose their homes because of loss of income. Some domestic violence victims must rely on shelters or depend on others to house them, and others become part of a community's homeless population, increasing their risk for other types of victimization. Medical expenses to treat injuries, particularly of uninsured victims, create additional financial burdens, either for the victims or for the public.

In the United States estimates of the percentage of homelessness among women resulting from domestic violence vary, but it may be upwards of 20 percent (National Coalition for the Homeless, 2004). In the United Kingdom, about 16 percent of the homeless to whom local authorities provided housing were victims of domestic violence (Office of the Deputy Prime Minister). A recent report from Australia found that domestic violence is a major contributing factor to homelessness. The study also found that more than one-third of those accessing government housing assistance for homelessness were women escaping domestic violence, and two-thirds of the children 
12

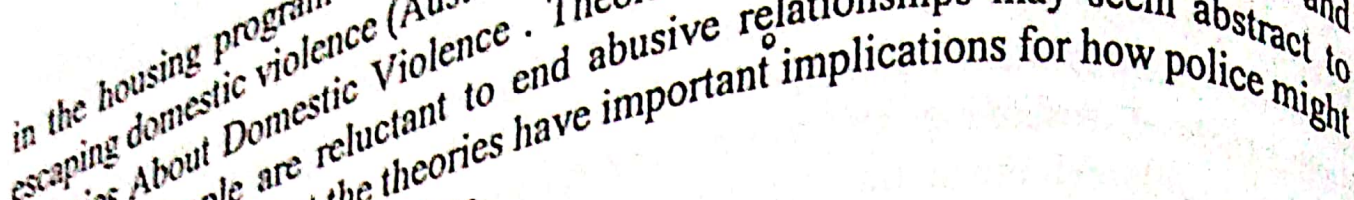

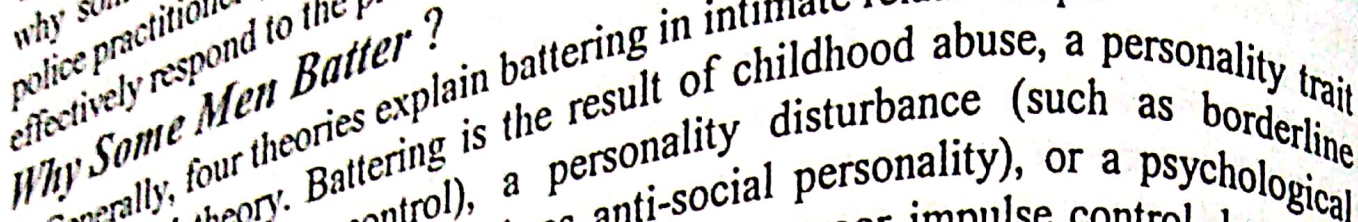

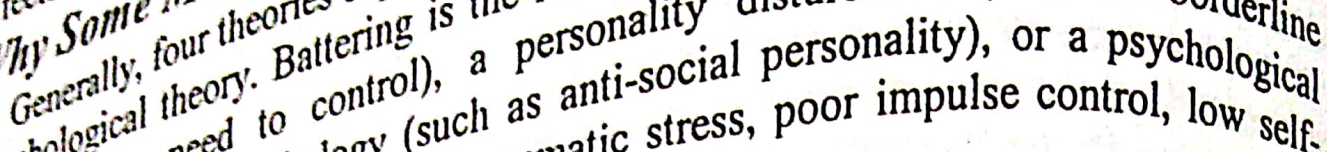
psitholog we need to thology (such as amatic stress, poor impulse control, low self.

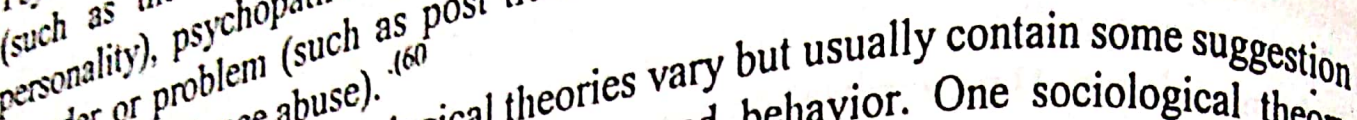
disorder or problance abuse). . al al theories vary behavior. One sociological theory

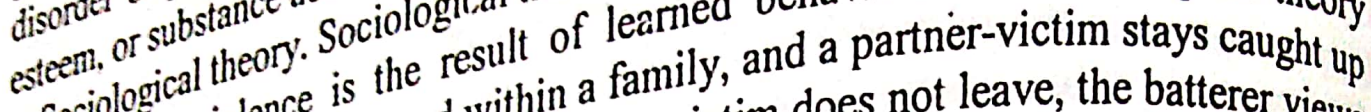
socilogical violence is the en within a family, an does not leave, the batterer views that intininate violence is learneriveness. If the victs. Children of these family members suggests that violence and forge vosion in a cyle ence as a way to prod their parents (boys ciological theory suggests that lower the violence the behavior from may become battering vill show higher rates of income subcultures will shon ing disputes in such subert people with resources (financial, more acceptable form or is in ill social systent in family members, while those without

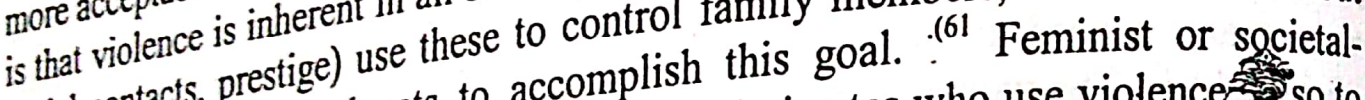
social contacts, prest and threats to accomplish intimates who use violence. resort to violence acording to this theory, male in artners. Societal traditions of male structural theory. Accil independence of wom relationships.

control and limport and sustain inequities in relt was assumed that domestic batterers dominanent individuals theory. For many years it was their current or former intimates they were a special group, that while they assanllere is cause to question how fully this were not violent in the outside wh full extent of violence batterers perpetrate is describes batterers. Although the follterers are violent beyond domestic violence, unknown, there is evidence that many for violent and non-violent behavior. ${ }^{.62} \mathrm{This}$ and many have prior criminal records for ve less unique and are more accurately suggests that domestic violence balts not solely as domestic batterers. There may be a group of viewed as violent criminals, not solely as current or former intimates and engage in no batterers who are violent only to criminal behavior, but this group may be small compared to the more common type of batterer. ${ }^{63}$ Why Some Women Batter.

Some women batter their current or former intimates. Less is known about women who use violence in relationships, particularly the extent to which it may be in selfdefense, to fight back, or to ward off anticipated violence. When asked in a national survey if they used violence in their relationships, many Canadian college wortan said they did. However, the majority of these women said it was in self-defense or to fight back and that the more they were victimized the more they fought back. ${ }^{.64}$ One researcher suggests that women should be discouraged from engaging in minor 


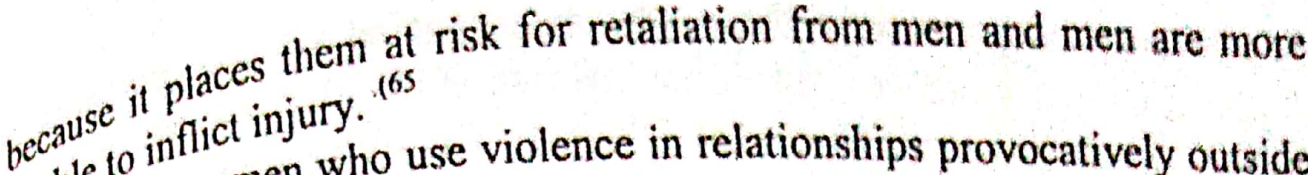

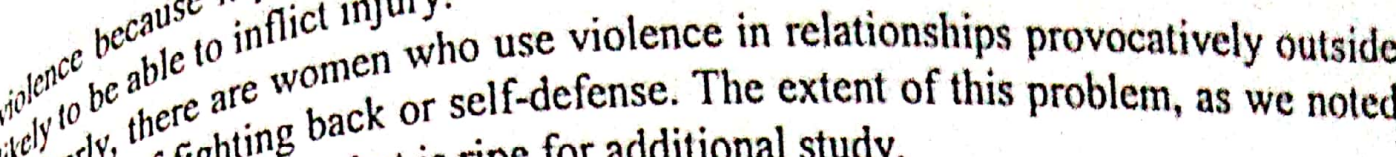
(i) cleas ly, of fighting back or self-defense. The extent of this problem, as we noted

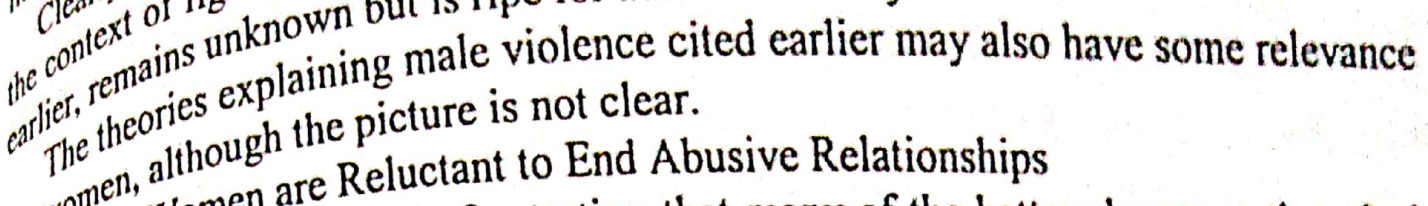

for $w^{\text {gr men }}$, Women are Reluctant to End Abusive Relationships

Whily lice commonly express frustration that many of the battered women they deal with do not leave their batterers. Although many women do leave physically abusive relationships, otheut the percentage of women who stay in physically abusive information abour Researchers offer a number of explanations for the resistance by some selationships. Reser. 166

to leave an abuser. Three cyclical phases in physically abusive intimate relationships cycle of vioman in the relationship: 1) a tension-building phase that includes minor keep a wal verbal abuse, 2) an acute battering phase, and 3) a makeup or physicymoon phase. The honeymoon phase lulls an abused woman into staying and the cycle repeats itself. ${ }^{.67}$

Battered woman syndrome. A woman is so fearful from experiencing cycles of violence that she no longer believes escape is possible. Stockholm syndrome. A battered woman is essentially a hostage to her batterer. She develops a bond with and shows support for and kindness to her captor, perhaps because of her isolation from and deprivation of more normal relationships. Traumatic bonding theory. A battered woman experienced unhealthy or anxious attachments to her parents who abused or neglected her. The woman develops unhealthy attachments in her adult relationships and accepts intermittent violence from her intimate partner. She believes the affection and claims of remorse that follow because she needs positive acceptance from and bonding with the batterer.

Psychological entrapment theory. A woman feels she has invested so much in the relationship, she is willing to tolerate the battering to save it.

Multifactor ecological perspective. Staying in physically abusive relationships is the result of a combination of factors, including family history, personal relationships, societal norms, and social and cultural factors. Factors Contributing to Domestic Violence

Understanding the risk factors associated with domestic violence will help you frame some of your. own local analysis questions, deternopriate esponses. Risk measures, recognize key intervention points, anon will become a domestic violence factors do not automatically mean the risk factors are stronger than others, it is victim or an offender. Also, although soms across studies because of methodological difficult to compare risk fac
differences between studies.

Age

The female age group at ho this high-risk age group undergraduate college students 24. ${ }^{.68}$ Among one segment osponts in a Canadian study red physically assaulting their vercent of female 14 percent of male resporimizand 674 


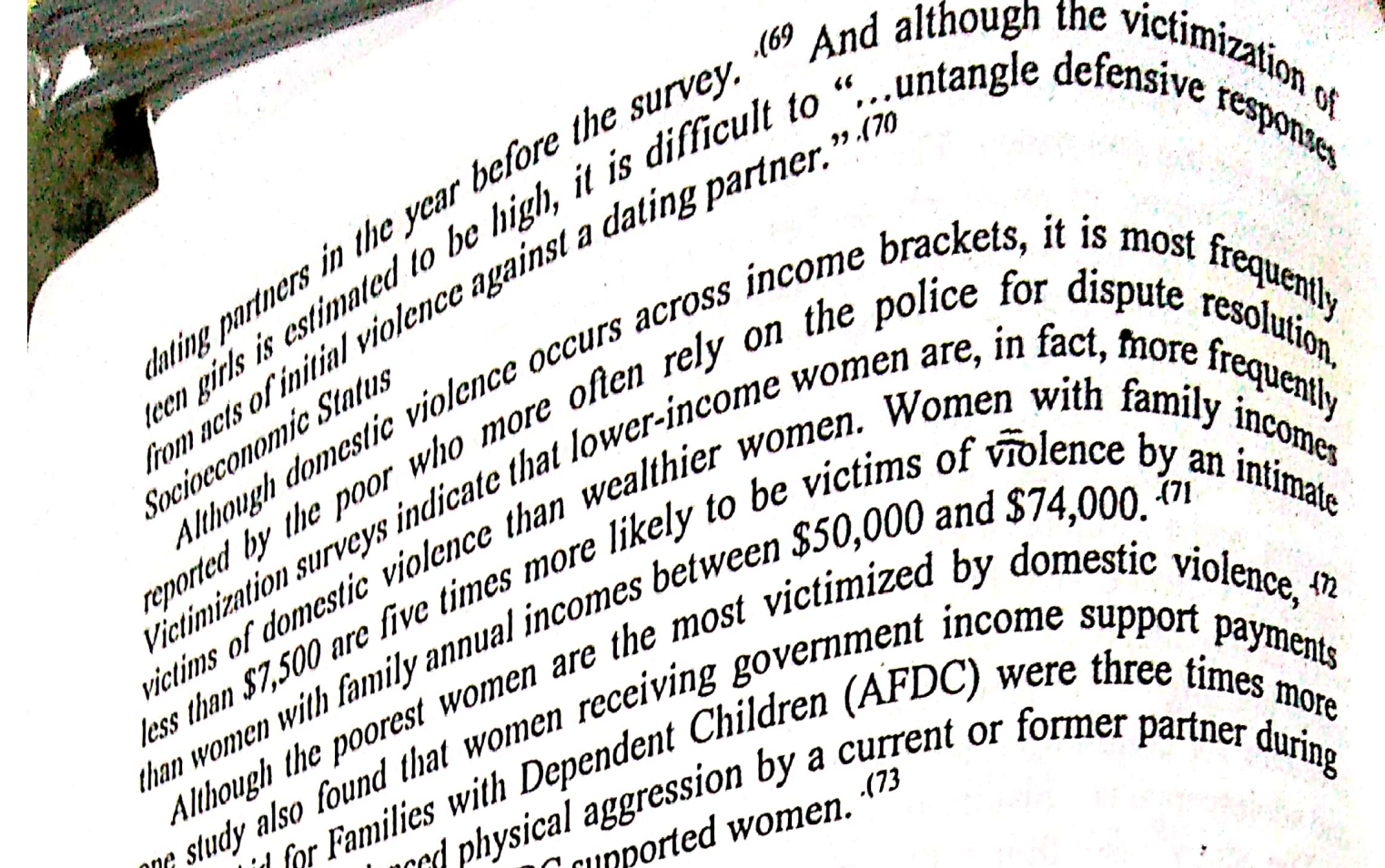

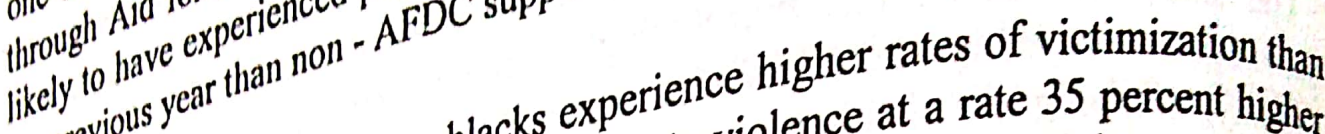

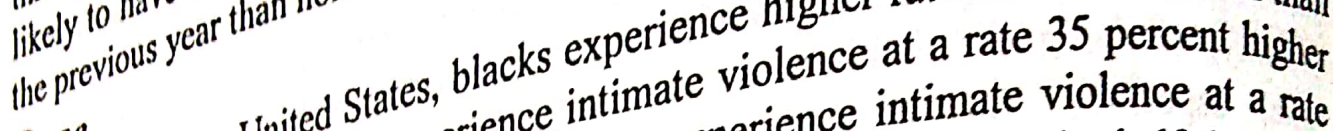
Race 0 verent in the Uniled States experience intimate experience intimate violence at a rate

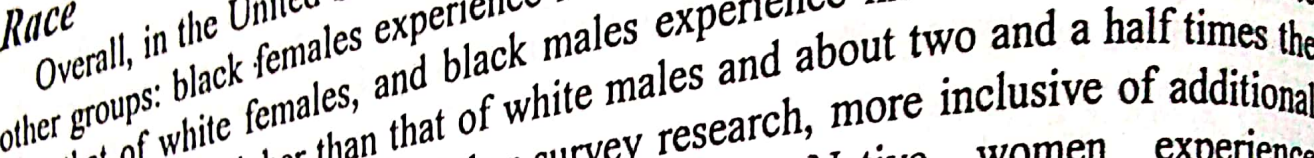

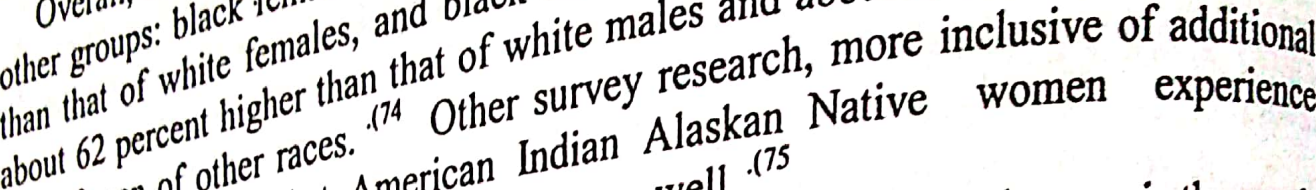
rale of men of ofterer that Americian Indian as well. ${ }^{175}$

racial eroups, inder rates of hhysical abuse as in victimization rates by race is the result

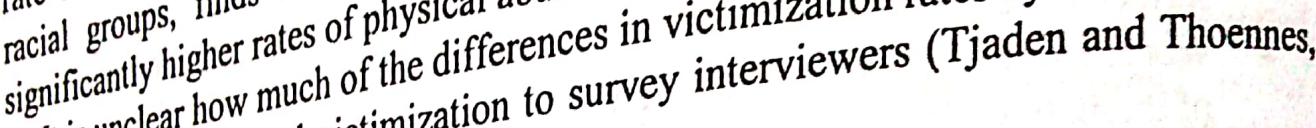
It is unclear to reveal victimization to survey int

2000).

Repeat Victimization Domestic violence, generally, Yorkshire (United Kingdom) showed that 42 percent For instance, police data in West Yikn one year were repeat offenses, and one-third of of domestic violence incidents were responsible for two-thirds of all domestic violence domestic violence offenders we. It is likely that some victims of domestic violence incidents reported to the police. It is and others experience it repeatedly ${ }^{177}$ over a experience physical assault only onces arch suggests that the highest risk period for period as short as 12 months. British research sug the last assault. ${ }^{7}$ Incarceration of further assault is within the first four weeks of the last a Offenders.

Offenders convicted of domestic violence account for about 25 percent of violent offenders in local jails and 7 percent of violent offenders in state prisons. Many of those convicted of domestic violence have a prior conviction history: more than 70 percent of offenders in jail for domestic violence have prior convictions for other crimes, not necessarily domestic violence. ${ }^{(79}$

\section{Termination of the Relationship}

Although there is a popular conception that the risk of domestic violence. increases when a couple separates, in fact, most assaults occur during a relationship rather than after it is over. However, still unknown is whether the severity (as opposed to the frequency) of violence increases once a battered woman leaves. ${ }^{(80}$ Pregnancy . 
opular belief, pregnant women are no more likely than non-pregnant
10 be victims of domestic violence. In fact, some women get a reprieve from (10) during pre physical abuse before the pregnancy.

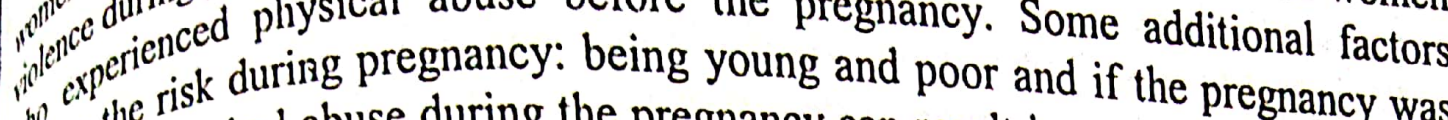
1. of se the physical abuse during the pregnancy can result in pre-term delivey was

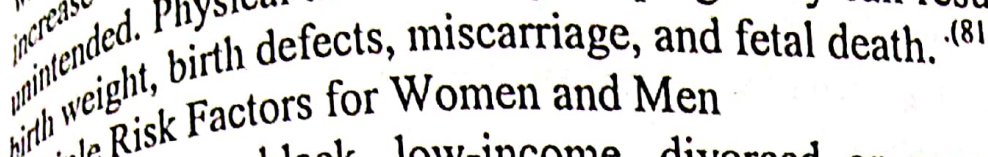

willip le Risk roung, black, low-income, divon

Being a resident of an urban arearced or separated, a resident of rental pols 1 ing, " jon nestic arly identical: being young, black, divorced or separated, or a resident of were retral predid dodolescence is a history of aggressive delinquency before age $15 .{ }^{.84}$

The study also found that committing partner violence is strongly linked to colabitation at a young age; a variety of mental illnesses; a background of family adversity; dropping out of school; juvenile aggression; conviction for other types of crime, especially violent crime; drug abuse; long-term unemployment; and parenthood at a young age. ${ }^{.85}$

\section{Other Risk Factors:}

Several other risk factors emerge from research:

- A verbally abusive partner is one of the most robust risk factors for intimate partner violence. ${ }^{(86}$

- Women whose partners are jealous or tightly controlling are at increased risk of intimate violence and stalking.

- There is a strong link between threat of bodily injury and actual bodily injury, suggesting that abuser threats should be taken seriously. ${ }^{.87}$

Recently, there is much discussion among police about the link between pet abuse and domestic violence. Although some overlap is likely, particularly under the theory that many batterers are generally violent, not enough is known because of the types of studies undertaken. Some small surveys of domestic violence shelter residents suggest that some women might have left their abuser sooner bup they worried about their pet's safety. ${ }^{\text {(88 }}$

Finally, although alcohol and drug use do not cause intimate partner battering, the risk of victim injury increases if a batterer is using alcohol or drugs.

Notwithstanding its decline over the last decade, domestic violence stubbornly remains a frequent call for police, and efforts to froblem. You must combine the basic specific information about the nature of your local problem. Analyzing the local facts with a more specific undeu design a more effective response strategy. ${ }^{\left({ }^{\circ}\right.}$

Stakeholders
In addition to criminal justice agencies, the following groups have contribution they the domestic violence problem and ought to broblem and responding to it: ${ }^{191}$ might make to gathering infortion, counseling, and advocacy organizations

- domestic abusel providers 


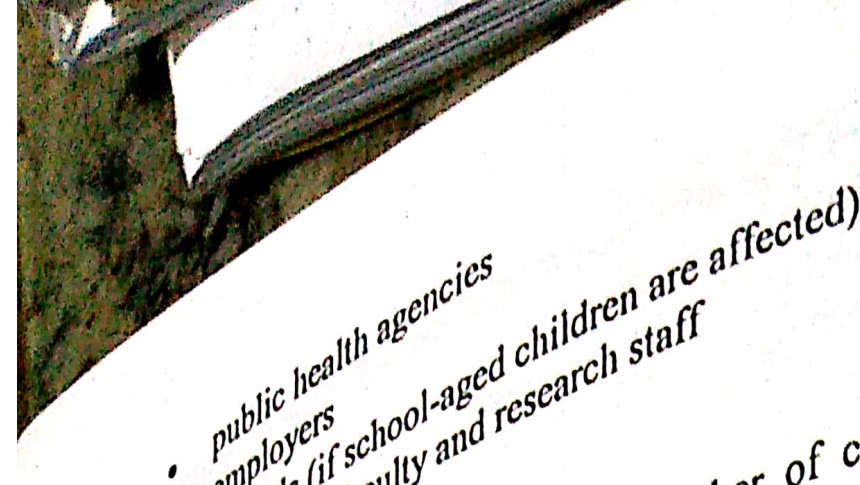

alls for police service in your

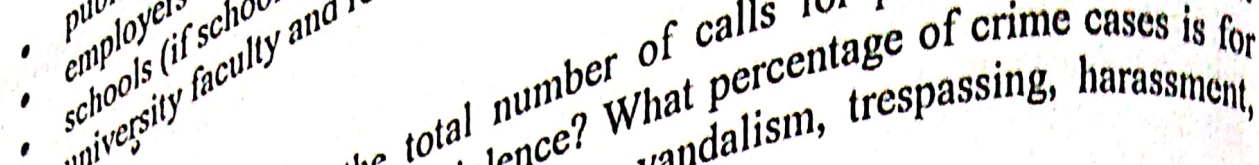
- clerg

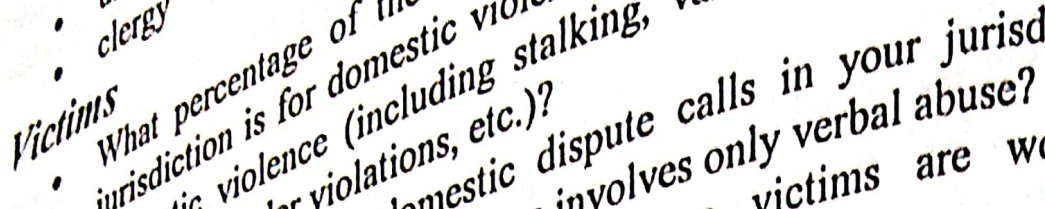

urisdiction involves

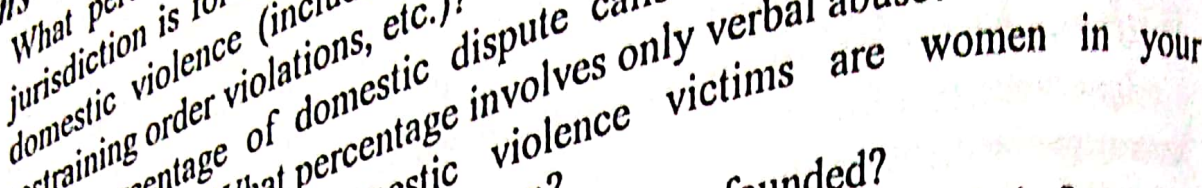
What percenthe? What percenstic dome are men? What percenthat percentag violence calls involves a repeat victim? juris diction ${ }^{2}$ enge of dom entic violence from repeat victims? What percentage of tome between for two calls to the police over

- What perce arerage account for Five calls? More than five cassault?

- What is the a victims accur calls? Five cant at the time of assault?

- How many calls? Fon is pregnant alls involves a cur percentage of crime period? That percentage of victimestic violence cals intimate? What

- What percentage or involves a form former intimate?

- percentage of calls int intimate versuce calls involves anmarried, separated, cases involves a domestic viol together, live-in unmon, dating?

What percentage married and living married but child in com when living together, relationships. married, never most serious (while dating, wher mored, neve

When was the violence mictions actually leaves their a violence victims Whon bercentage of domestic violence victims in the

- What percen police respond?
- What is the average age of reported domestic victions who are homeless?
jurisdiction? Wurisdiction? - What is the Problem of Domestic Violence Responses analysis of Our local problem should giv your jurisdiction. Once we have Our analys os vic violence cases and calls in $f$ it and establine for patterns of dom local problem or important aspects of oussible responses to address the measuring effectiveness, we should consider possintive problem.

These strategies are drawn from a variety of sources, including descresponses materials, research studies, and police reports. It is critical that you will involve based on reliable analysis. In most cases, an effective strategyenses alone are implementing several different responses. Law enforcem not limit ourselves to seldom effective in reducing or solving the problem. Do not limit oursum who considering what police can do: carefully consider others in your com in some share responsibility for the problem and can help police better respond to it. In som 
政

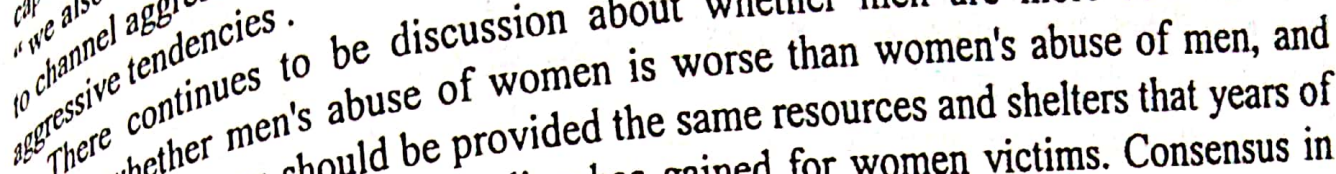

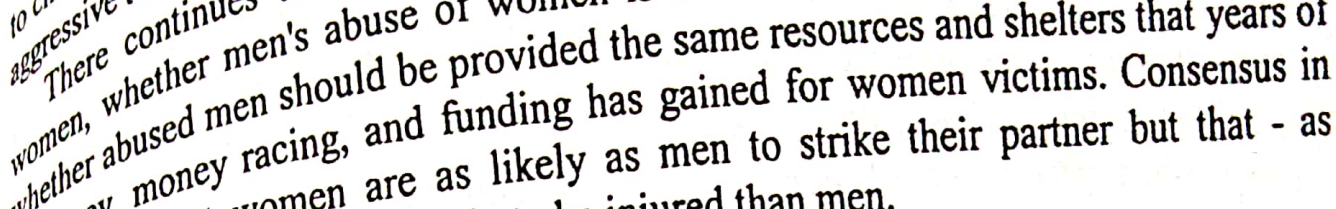
ab fucald is that women are as likely as men to strike

expected - women aredge there can be no morality? Without knowledge there can be no morality?

Ignorance is a fas been insisted upon by the writers who have most vehemently was organized, havor of the superiority of man; a superiority not in degree, but offence; argued in to soften the argument, they have labored to prove, with hidalgos generosity, thought, thexes ought not to be compared; man was merfect whole, by blending happily that together, flesh and spirit, che character.

reason and sensibility int "Quickness of sensation, quickness of perception, delicacy." And what is sensibility? "Qunson; and the definition gives me no other idea than of the Thus is it defined by Dished instinct. I discern not a trace of the image of God in either immortal soul, she must have, as the If woman be allowed to have an immortal And when, to render the present employment of life, an understanding to imper it to be but a fraction of a mighty state more compled by present gratification to forget her grand destination of every sum, she is inciled bo was born only to procreate and rot counteracted, or she wough not a reasonable one, the exercise of attainment of reason in may be the step which they are to take, in this life, toward man, who, why we cannot the next; so that through all eternity they will in his first mode of existence. tell, had the power given him of attien of women, as I should treat of the peculiar duties When I treat of the peculiar du found that I do not mean to insill "He that hath wife and of a citizen or father, it will be families, speaking of the majority. "Hildren, understanding, in be taken out of their fation of a family, in the educationgth both of body and mind; yet children, In the regulation is particularly required stly labored to domesticate women, an unsophisticated their writings, have most earn by a gross appetite, which sate even by the men who, by dey arguments dictales and cramp their minds. Bueir feelings, to have end devourtious, to weaken their bodies a wen, by working on themily, I should these sinister methods they really persto a mother and mistress of a viling on them to stay at home, and fulfill the dut led women to right conduct, bus of life, though reason cautiously oppose opinions important duties the main be such

make the discharge of such important
were insulted.
Yet, and I appeal to experience, if by neglecting the under standing the the be by much, nay, more detached from these domestic 678 


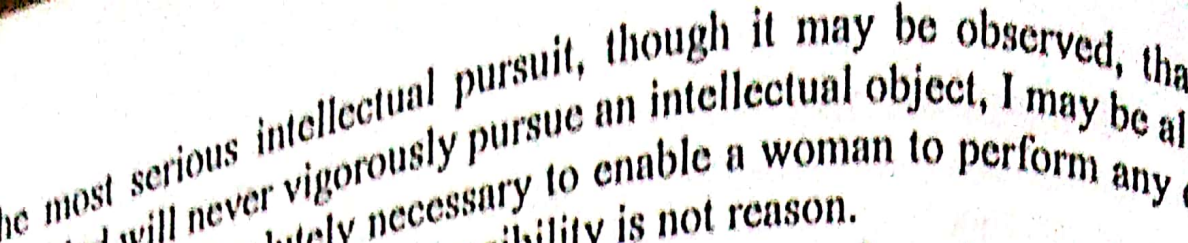

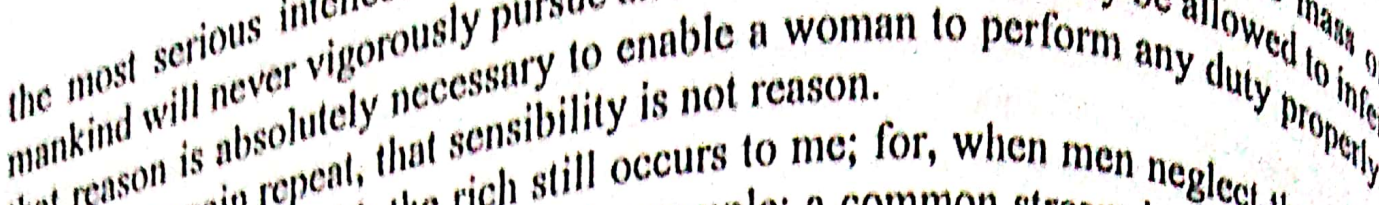

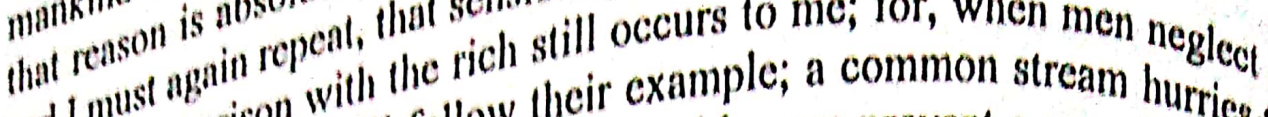
The comparison wen will follow their ex and honors prevent a man from on the oul io

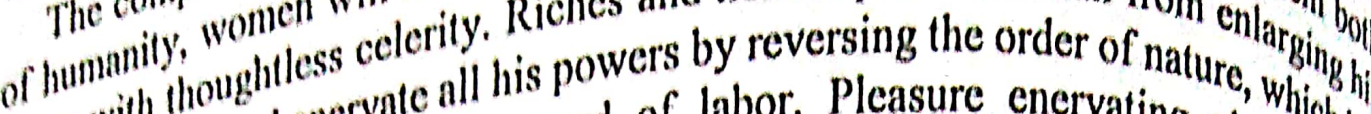
along with thing and enervate all his pard of labor. Pleasure enervating understanding, anc pleasure the we without earning it. But, till hereditary pleasupe hat ever made thithin women's reach with men to be proud of virtue? And, till tong ap likewise, with how can we expect most direct means, neglecting their dull spread abroad, wovern them by the mosh sits lightly on the wing of time. women will go pleasure that sits duties to calch the when I write with affectionate sofferent from that reciprocative, degree of attention and respect fromity and the politeness of civilization auth of civility which the dictates of the And why do they not discover, when "in the noon of beauty's between man and mane treated like queens only to be deluded by hollow respect, till power," that they anc in not assume, their natural prerogatives? Confined, then, in they are led to resign, aree, they have nothing to do but to plume themselves, and cages like the feathered from perch to perch.

stalk with mock majess a king, and a woman always a woman.

A king is always a kex stand between them and rational converse. With a His authority and her sex should be so, and her sensibility will naturally lead her to endeavor lover, I grant, she should be so, and hanity, but her heart.

to excite emotion, not every description, wish to be loved and respected by

Mankind, including common herd will always take the nearest road to the completion something, and the corsect paid to wealth and beauty is the most certain and of their wishes. The rourse, will always attract the vulgar eye of common minds. unequivocal, and, of are absolutely necessary to raise men from the middle rank of Abilities and vice, and the natural consequence is notorious the middle rank contains life into notice, and the station an an least, an op most virtue and abilities. Mignity, and of rising by the exertions which really improve exerting themselves with dis whole female sex are, till their character is formed, in the same condition as the rich, for they are gratuitously granted them, few will with certain sexual privileges; and whilst they are gratuitously gran a small number of
ever think of works of supererogation to obtain the esteem of a superior people.

When do we hear of women who, starting out of obscurity, boldly claim respect on account of their great abilities or daring virtues? Where are they to be found? "To be observed, to be attended to, to be taken notice of with sympathy, complacency, and approbation, are all the advantages which they seek." True! my male readers will probably exclaim; but let them, before they draw any conclusion, recollect that this was not written originally as descriptive of women, but of the rich.

Women, commonly called ladies, are not to be contradicted in company, are not allowed to exert any manual strength; and from them the negative virtues only are expected, when any virtues are expected patience, docility, good humor, and 
fexibility virtues incompatible with any vigorous exertion of intellect. Besides, by jining pluence of sentiments than passions. Solitude and reflection are more under $\|{ }^{2} 10$ wishes the force of passions, and to enable the imagination are necessary to give and make it the most desirable. The same may be said of ation to enlarge the objecl, intly deal in general ideas, collected by impassioned the rich; they do not sulficition, to acquire that strength of character on which thinking or calm investig what an acute observer says of the great. Do the great resolves are built. But hear ace at which they may acquire the public ad great seem insensible of the easy price that to them, as to other men, it must be admiration; or do they seem to inagine By what important accomplishments is the purchase either of sweat or of blood? Bup the dignity of his rank, and to rende is the young nobleman instructed to his fellow-citizens, to which the virtue of his ancerthy of that superiority over knowledge, by industry, by patience, by self denial, or by vised them? Is it by his words, as all his motions are attended to he leams an circumstance of ordinary behavior, and studies to perform all those small to every the most exact propriety. Ashe is conscious how much he is observed, mankind are disposed to favor all his inclinations, he acts, upon the most indifferent occasions, with that freedom and elevation which the thought of this naturally inspires. His air, his manner, his deportment, all mark that elegant and graceful sense of his own superiority, which those who are born to inferior station can hardly ever arrive at. These are the arts by which he proposes to make mankind more easily submit to his authority, and to govern their inclinations according to his own pleasure; and in this he is seldom disbar pointed. These arts, supported by rank and preeminence, are, upon ordinary occasions, sufficient to govern the world.

In the middle rank of life, to continue the comparison, men, in their youth, are prepared for professions, and marriage is not considered as the grand feature in their lives; whilst women, on the contrary, have no other scheme to sharpen their faculties. It is not business, extensive plans, or any of the excursive flights of ambition, that engross their attention; no, their thoughts are not employed in rearing such noble structures. To rise in the world, and have the liberty of running from pleasure to pleasure, they must marry advantageously, and to this object their time is sacrificed, and their persons often legally prostituted.

A man when he enters any profession has his eye steadily fixed on some future advantage (and the mind gains great strength by having all its efforts directed to one point), and, full of his business, pleasure is considered as mere relaxation; whils women seek for pleasure as the main purpose of exe pleasure may be said to education, which they receive from sociely the is a sex in souls? govern them all; but does this prove fored by the whole tendency of their education, The same love of pleasure, for women in most circumstances; for instance, they gives a trifling turn to the conduct of ws; and on the watch for adventures, instead of

A man, when he undertakes a journey, has, in genge things that may possibly occur thinks more of the incidental occurrences, lake on her fellow travelers; and, above all, 
10. wisthes the force of passions, and to enable the imagination to enlarge the 6. aject, and deal in general ideas, collected by impassioned thinking or calm

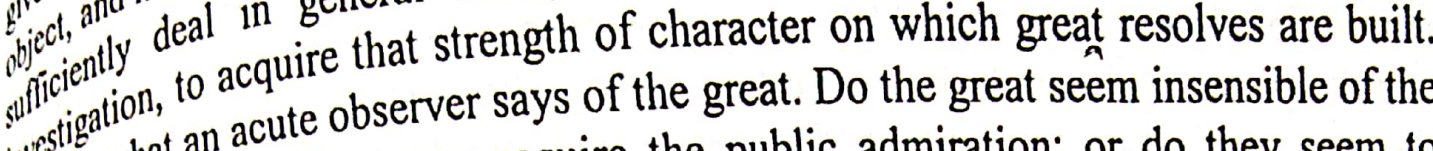
in the when what an acute observer says of the gublic admiration; or do they Bun price at which they may acqu, it must be the purchase either of sweat or in agine that to what important accomplishments is the young nobleman instructed to blo0? support the ditizens, to which the virtue of his ancestors had raised them? Is it by

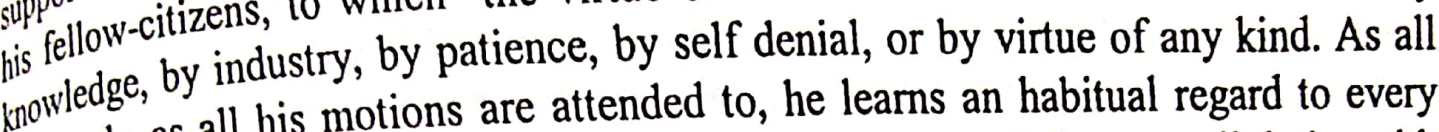
his words, as all his motions are attended to, he learns an habitual regard to every circumstance of ordinary behavior, and studies to perform all those small duties with the most exact propriety. Ashe is conscious how much he is observed, and how much mankind are disposed to favor all his inclinations, he acts, upon the most indifferent occasions, with that freedom and elevation which the thought of this naturally inspires. His air, his manner, his deportment, all mark that elegant and graceful sense of his own superiority, which those who are born to inferior station can hardly ever arive at. These are the arts by which he proposes to make mankind more easily submit to his authority, and to govern their inclinations according to his own pleasure; and in this he is seldom disbar pointed. These arts, supported by rank and preeminence, are, upon ordinary occasions, sufficient to govern the world.

In the middle rank of life, to continue the comparison, men, in their youth, are prepared for professions, and marriage is not considered as the grand feature in their lives; whilst women, on the contrary, have no other scheme to sharpen their faculties. It is not business, extensive plans, or any of the excursive flights of ambition, that engross their attention; no, their thoughts are not employed in rearing such noble structures. To rise in the world, and have the liberty of running from pleasure to pleasure, they must marry advantageously, and to this object their time is sacrificed, and their persons often legally prostituted.

A man when he enters any profession has his eye steadily fixed on some future advantage (and the mind gains great strength by having all its efforts directed to one point), and, full of his business, pleasure is consid of existence. In fact, from the women seek for pleasure as the main pecty, the love of pleasure may be said to education, which they receive from sociely, there is a sex in souls?

govern them all; but does this prove fhat by the whole tendency of their education,

The same love of pleasurduct of women in most circumstances; for instance, they gives a trifling turn to the condary things; and on the watch for adventures, instead of are ever anxious about second duties. A man, when he undertakes a journey, has, stange things that may possibly occur thinks more of the incidental occurre may make on her fellow travelers; and, above all, on the road; the impression that she may 
she is anxiously intent on the care of the finery that she carries with more than ever a part of general, as well as the rich of both sexes, have achish is

In shot, women, when they receive a careful education, they are either made fine ladies, brimfonen, sensibility, and honest crentures, and have a shrewd kind of good sen The latter are oflen friendydence, that oflen render them more useful members "of society jon with wor sentimental lady, though they possess neither greatness of mind nor taste than intellectual world is shut against them. Take them out of their family or neighborhood, and they stand still; the mind finding no employm , for literature affords a fund of amusement which the cultivated minds appear ridiculous antly $t_{\text {, }}$ despise. The sentiments and family connections have led them to love; but inen in acquaintance they think it all affectation.

Yet if love be the supreme good, let woman be only educated to inspire it, and let every charm be polished to intoxicate the senses; but if they be moral beings, let them have a chance to become intelligent; and let love to man be only a part of that glowing flame of universal love, which, after encircling humanity, mounts in grateful incense to God.

To fulfill domestic duties much resolution is necessary, and a serious kind of perseverance that requires a more firm support than emotions, however lively and true to nature. To give an example of order, the soul of virtue, some austerity of behavior must be adopted, scarcely to be expected from a being who, from its infancy, has been made the weathercock of its own sensations. Whoever rationally means to be useful must have a plan of conduct; and in the discharge of the simplest duty, we are often obliged to act contrary to the present impulse of tenderness or com passion. Severity is frequently the most certain as well as the most sublime proof of affection; and the want of this power over the feelings, and of that lofty, dignified affection which makes a person prefer the future good of the beloved object to a present gratification, is the reason why so many fond mothers spoil their children, and has made it questionable whether negligence or indulgence be most hurtful; but I am inclined to think that the latter has done most harm.

And those people who follow, with interest and admiration, the flights of "genius; or, with cooler approbation suck in the instruction which has been elaborately prepared for them by the profound thinker, ought not to be disgusted, if they find the former choleric, and the latter morose; because liveliness of fancy, and a tenacious comprehension of mind, are scarcely compatible with that pliant urbanity which leads a man, at least, to bend to the opinions and prejudices of others, instead of roughly confronting them.

But, treating of education or manners, minds of a superior class are not to be considered, they may be left to chance; it is the multitude, with moderate abilities, who call for instruction, and catch the color of the atmosphere they breathe. This respectable concourse, I contend, men and women, should not have their sensations heightened in the hot-bed of luxurious indolence, at the expense of their under standing; for, unless there be a ballast of understanding, they will never become either 


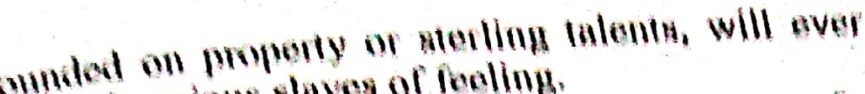

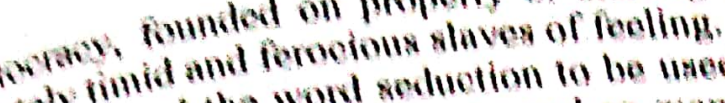

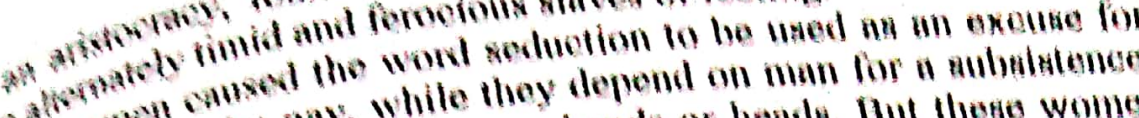

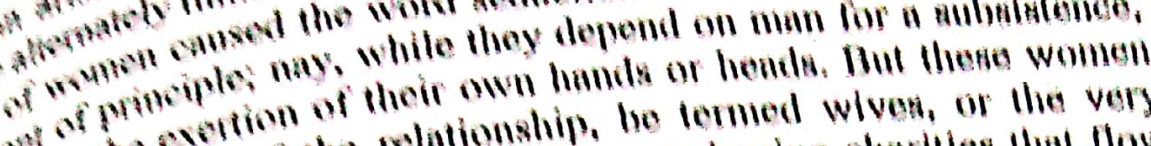

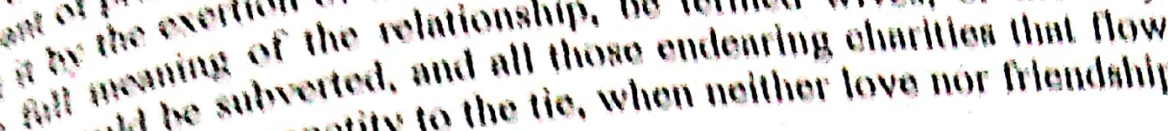

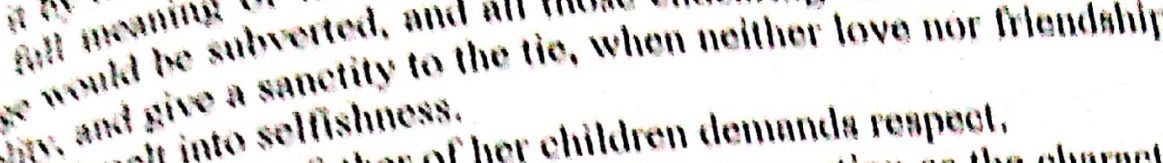

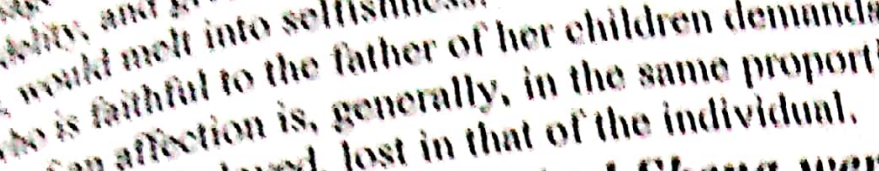

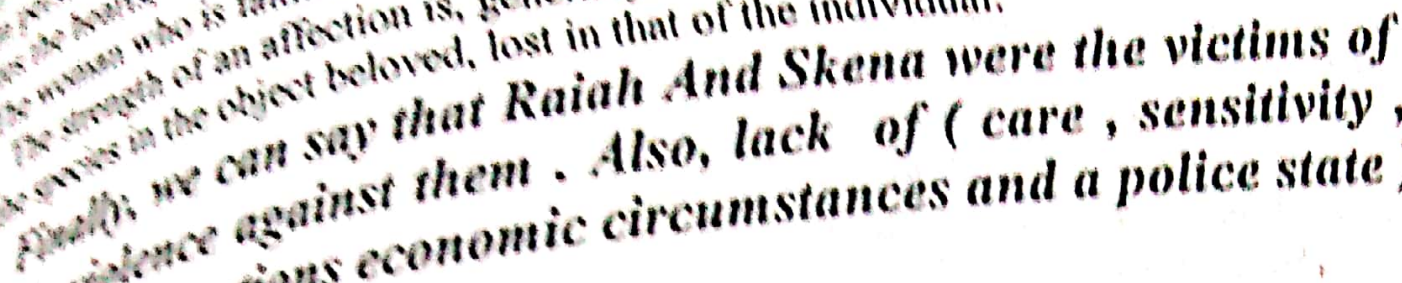

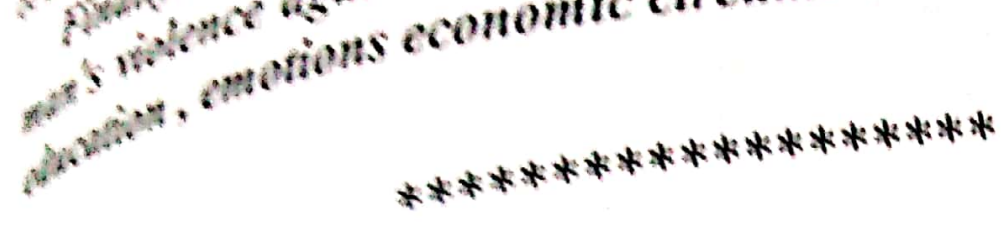




\section{REFERENCES}

Violence, Retrieved January 8 ,
tionary

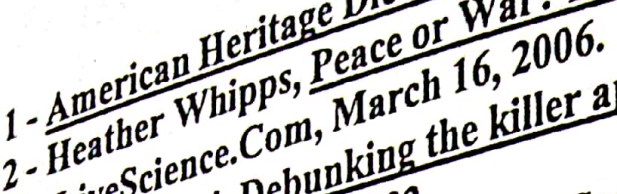

3.Cindy Fazzi, Debunk 2002.

5- Hans-Hermann Hopertanism: Ethics of Libertarappa, Editor, Formed abad, India, 1949.

6- Bharaja ${ }_{\text {Navaivan Publishing Honce. }}$.

7-CDCDefinition of Violenge and Heart Best Book.

8- World Report an , Violence. Hardt, Hannal, Boudicca's brutal streak, The Observer, 3 9 - Arendt, Hurke, Dig uncovers Bous
10 - Jason Bu 2000 .
December Before Civilization by Lawrence H. Keeley, July,

Handbook (PDF). Federal Bureau of 2004.

in International Conflict, in Investigation. 2004: Religion and Ideology in It: The Foundations of

13- Doctre Kuklick' (advisory ed.), The Monist 2006), p. 46. International Order, Vol. 89, No. 2 (Apr.

14 - Colombia's Uribe wins se. Violence and Non-Violence at Different

15 - Nazaretyan, A.P. (2007). humanitarian balance.

16 - Walter Benjamin's Critique of Violence.

17- Passive Aggressive Behavior, a Form of Covert Abuse

18 - Damm Violence.

19 - Wallace, Harvey (2004). Family Violence: Legal, Medical, and Social Perspectives. Allyn \& Bacon .

20 -Mayhew, P., Mirlees-Black, C. and Percy, A. (1996). The 1996 British Crime Survey England \& Wales. Home Office.

21 - About Domestic Violence. Office on Violence Against Women.

22 - The Physical and Psychological Effects of Domestic Violence on Women.

23 - Archer $\mathrm{J}(2002)$. Sex differences in physically aggressive acts between heterosexual partners A meta-analytic review. Aggression and Violent.

24 - Watts C, Zimmerman C (April 2002). Violence against women: global scope and magnitude.

25 - Passive Aggressive Behavior, a Form of Covert Abuse.

* Domestic Violence Assessment Policy (PDF). Children and Family Court Advisory and Support Service.

26 - Kalmuss, D.S. and M.A. Straus. Wife's Marital Dependency and Wife 
1 se. in Straus and Gelles. Physical Violence in American.
Harrykissoon SD, Rickert VI, Wiemann CM (April 2002).

and patterns of intimate partner violence among adolescent mother

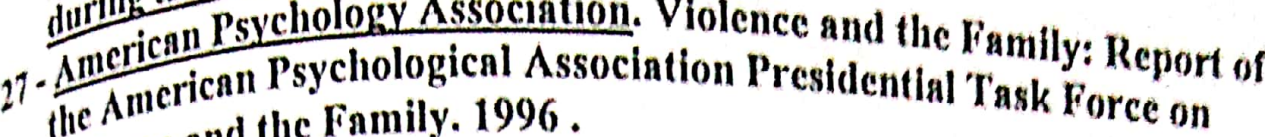

the Allere and the Family. 1996.

- Battering and C.G. Buznwa. Domestic Violence Teminist View. in Buzawn, Justice Responsc. Auburn House.

25-Archer, J. (2000). Sex differences in aggression between heterosexual

partners: A meta-analytic review. Psychological Bulletin.

29- Violence in Media Entertainment; Childhood Exposure to Media Violence Pror Study American Psychologive Behavior, According to a New 15-year Study, American Psychological Association press release, March 9, 2003.

30- Nineteenth Century Death Tolls

31 - Ending Violence Against Women, Population Reports (PDF). Center

for Health and Gender Equity (CHANGE). December 1999

32- Commentary transferred to Huang Jing regarding the supplementary plan to suppress counterrevolutionaries in Tianiin

33-The Black Book of Communism: Crimes, Terror, Repression by

Stephane Courtois, et al; China: $A$ Long March into Night by Jean-

Louis Margolin, pg 479 .

34 - Twentieth Century Atlas - Homicide

* O'Leary 1993

* Chornesky 2000

* Doumas, Margolin, \& John, 1994

* Crowell \& Burgess, 1996

* Hotaling \& Sugarman, 1986

35 - Bancroft, Lundy. Why does he do that? Inside the minds of angry and controlling men Berkley Publishing Group 2002.

36- Hall RC, Zisook S (1981). Paradoxical reactions to benzodiazepines.

37 - Jewkes, Rachel (April 20, 2002). Intimate partner violence: causes and prevention.

38 - Hall RC, Zisook S (1981). Paradoxical reactions to benzodiazepines.

39 - Benzodiazepines: Paradoxical Reactions \& Long-Term Side-Effects

40 - Hansson O, Tonnby B (March 1976). Serious psychological symptoms caused by clonazepam (in Swedish). Lakartidningen 73.

41 - Sushma Kapoor ( June,2000). Domestic Violence Against Women and Girls. UNICEF: Innocenti Research Centre.

42 - Male Victims of Domestic Violence.

43- Lawrence A. Greenful et al (1998). Violence by Intimates.

44 - M.A. Straus (1999). The controversy over domestic violence by women: A methodological, theoretical, and sociology of science analysis. In X.B. Arriaga \& S. Oskamp Eds.), Violence in Intimate

Relationships. 


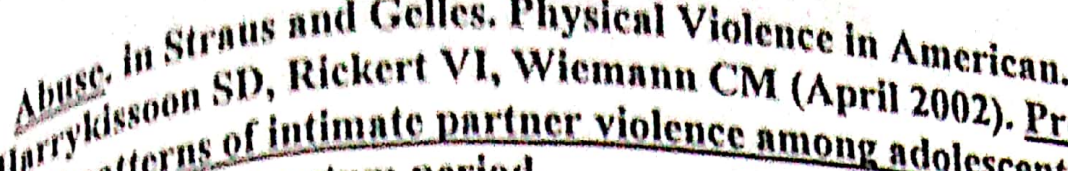

- 1ij ipgeres of intimate partner violence among adolescent mother

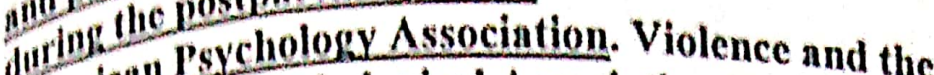

27 - Anctic Ancrican Psychological Associntion Presidential Family: Report of

violence and the Family. 1996.

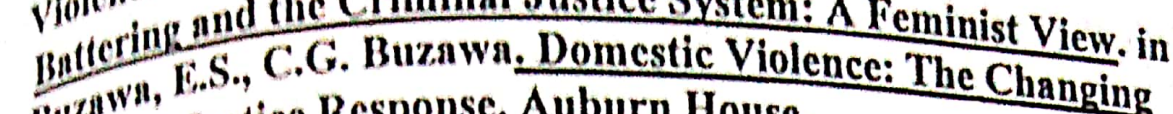

Buzilw, Justice Response. Auburn House.

Crimer, J. (2000). Sex differences in aggression between heterosexual

88- Ariners: A meta-analytic review. Psychological Bulletin.

violence in Media Entertainment; Childhood Exposure to Media

29) Violence Predicts Young Adult Aggressive Behavior, According to a

New 15-year Study, American Psychological Association press release,

March 9, 2003.

30 - Ninetecnth Century Death Tolls

31- Ending Violence Against Women, Population Reports (PDF). Center

for Health and Gender Equity (CHANGE). December 1999

plan to suppress counterrevolutionaries in Tianiin

33 - The Black Book of Commmunism: Crimes, Terror, Repression by

Stephane Courtois, et al; China: $A$ Long March into Night by Jean-

Louis Margolin, pg 479 .

34 - Twentieth Century Atlas - Homicide

* O'Leary 1993

* Chornesky 2000

* Doumas, Margolin, \& John, 1994

* Crowell \& Burgess, 1996

* Hotaling \& Sugarman, 1986

35 - Bancroft, Lundy. Why does he do that? Inside the minds of angry and controlling men Berkley Publishing Group 2002.

36 - Hall RC, Zisook S (1981). Paradoxical reactions to benzodiazepines.

37 - Jewkes, Rachel (April 20, 2002). Intimate partner violence: causes and

prevention.

38 - Hall RC, Zisook S (1981). Paradoxical reactions to benzodiazepines.

39 - Benzodiazepines: Paradoxical Reactions \& Long-Term Side-Effects

40 - Hansson O, Tounby B (March 1976). Serious psychological symptoms caused by clonazepam (in Swedish). Lakartidningen 73.

41 - Sushma Kapoor ( June,2000). Domestic Violence Against Women and Girls. UNICEF: Innocenti Research Centre.

42 - Male Victims of Domestic Violence.

43 - Lawrence A. Greenful et al (1998). Violence bv Intimates.

44 - M.A. Straus (1999). The controversy over domestic violence by women: A methodological, theoretical, and sociology of science analysis. In X.B. Arriaga \& S. Oskamp Eds.), Violence in Intimate

Relationships. 

47 - Stralls, Mor Male and remialc

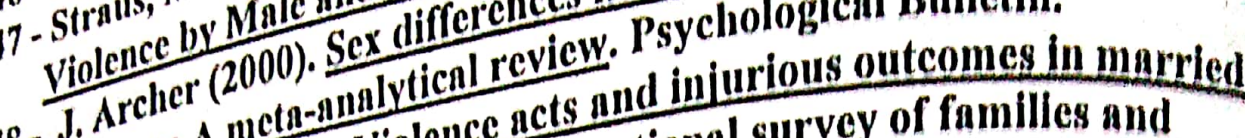
48- . Aers: A meta-1 Violence acts and in national survey of familles and 49- L.D. Brush (1) Methodological issues in

couppe: Mouseholds.

50- Michael R. Rand \& Kerrency Room Departments.

Treated in Hospital Emeres (1986). Gender differnces in courtship violence.

51 - Jamily Relations, Family Bocks $A C$, Levendosky $A A$, Bog on matermal and infant healith. 52 - Huth-Bo violence during pregntan

Violence Vict 17.000$)$. Conflict and Control: Images of Symmetry and 53 - Johnson, M.P. (200). Co Violence. in Booth, A., A.C. Crouter, and M. Asvmmetry in Dorles in Conflict. Erlbaum .

Clements. Couplesin,

Gottman (1998). When Men Batter Women: New

Insights into Ending Abusive Relationships. Simon \& Schuster.

55 - Reconciliation After Violent Conflict. A Handbook.

Institute for Democracy and E. Saltzman (August 1995 Violence against

56-Bachman, Ronet and Lind the Redesigned Survey. Bureau of $\triangle J_{u s t i c e}$

US - Overview. Bureau of Justice

57 - Intimate Parther Violence in the U.S.

Statistics.

58 - "Power and Control Wheel" (PDF). Domestic Abuse Intervention

Project.

59 - Benzodiazepines, Paradoxical Reactions \& Long-Term Side-Effects.

60 - Twentieth Century Democide; Atlas Wars and Democide of the

Twentieth Century.

61 - Court Cases with Allegations of Multiple Sexual And Physical Abuse of Children.

62 - Terrorism and Political Violence.

63 - Straus MA (1980). A Sociological Perspective on the Causes of Family

Violence, in Green MR. Violence and the Family. Westview.

64 - Rummel, R.J. Statistics of Democide: Genocide and Mass Murder since 1900 Chapter 3. LIT Verlag Münster-Hamburg-Berlin-WienLondon-Zürich (1999) .

65 - B.J. Morse (1995). Beyond the conflict tactics scale: Assessing gender differences in partner violence. Violence and Victims.

66 - Michael Cassidy, Caroline G. Nicholl, \& Carmen R. Ross (2001). Results of a survey Conducted by the metropolitan ${ }^{\circ}$ Police 


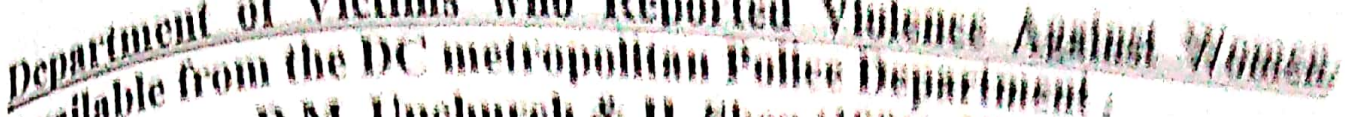

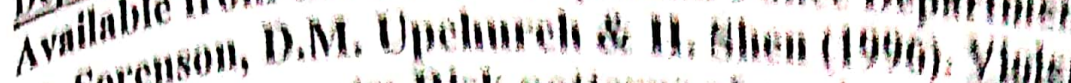

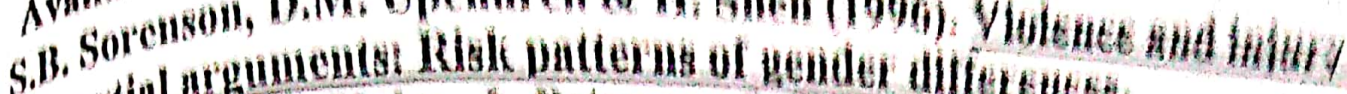

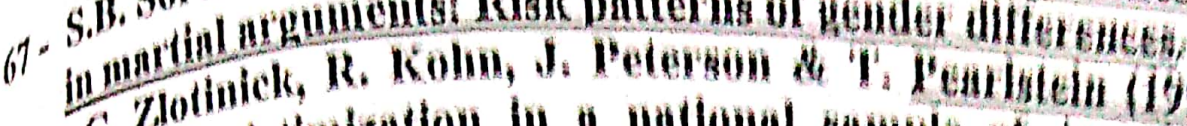

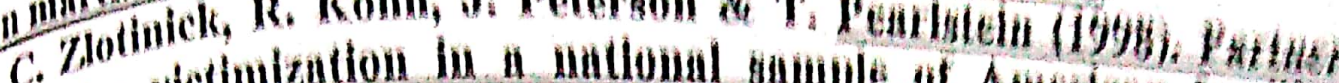

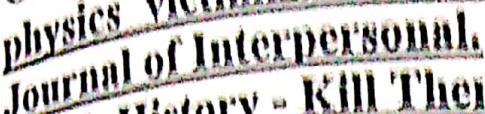

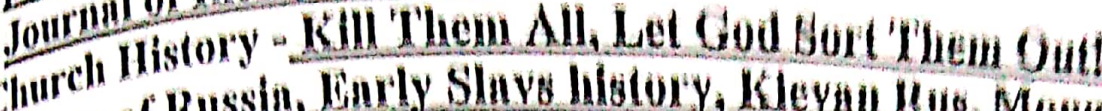

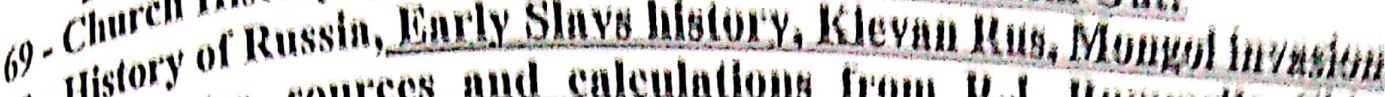

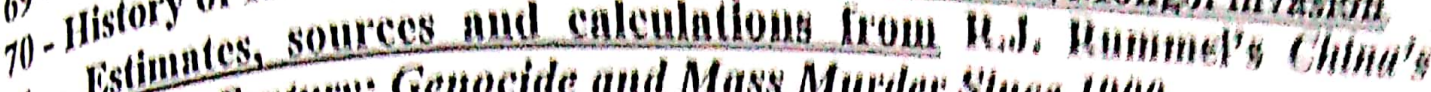

71 - Blondy Century: Genocide and Mass Murider Silnee 1900)。

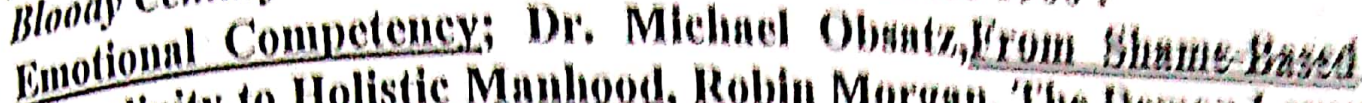

72 - Masculimity to Holistic Mamhood, Robin Morgan, 'the Demem Later

On the Sexuality of 'Terrorism, W.W. Norton, 1989), Chapters.

73 - American Civil War, Bucrelopadia Britamuica

73 Quam, Michacl D. C
Karamjoa, Uganda., 1996 .

74 - True hell on carth: Simon Maun faces imprisonment in the eruetlest

jail on the planet.

75- Borderline Personality Disorder: Diagnostic and Statistical Manual of
Mental Disorders. Psychiatry Online.

76- Gottesman, Ronald, ed. Violence in America: An Encyclopedia. New
York: Charles Scribner's Sons, February 1, 2000.

77 - Vayrynen, R., ed. To Settle or to Transform? Perspectives on the

Resolution of National and International Conflicts. London,

Newbury Park, New Dehli: SAGE Publications, 1991.

78 - Barkan, Steven E. and Lynne L. Snowden. Collective Violence.

Boston: Allyn \& Bacon, March 1, 2000.

79 - Goode, William (1971). Force and Violence in the Family. Journal of

Marriage and the Family 33.

80 - Hamberger, L. K., J. E. Hastings (1986). Personality Correlates of Men

Who Abuse Their Partners: A Cross-Validation Study. Journal of

Family Violence 1 .

81 - Boyle, A., S. Robinson and P. Atkinson (January 2004). Domestic

Violence in Emergency Medicine Patients. Emergency Medicine

Journal 21 .

82 - Hart, S. D., D. G. Dutton, T. Newloves (1993). The Prevalence of

Personality Disorder Among Wife Assaulters. Journal of Personality

Disorders 7.

83 - Stephen Pinker, The History of Violence, The New Republic, March

19, 2007.

84 - Roberts, A.R. (1996). Battered Women Who Kill: A Comparative Study of Incarcerated Participants with a Community Sample of Battered Women". Journal of Family Violence.

85 - Holtzworth-Munroe, A., and G. L. Stuart (1994). Typologies of Male

Batterers: Three Subtypes and the Differences Among Them.

Psychological Bulletin . 
86 - Johnson, M.P. (1995). Patriarchal Terrorism and Common Couple Violence: Two Forms of Violence Against Women. Journal of Marriage and the Family.

87 - Callic Marie Rennison (2001). Intimate Partner Violence and Age of Victim, 1993 - 1999.13urea of Justice Statistics Special Report. Wachington DC: U.S. Department of Justice .

88 - Dutton, D. G., S. K. Golant (1995). The Batterer: A Psychologica Profile. Basic Books.

89 - Burton, John W. Violence Explained: The Sources of Conflict, Violence and Crime and Their Prevention. New York: Manchester University Press, July 1997.

90 - Galtung, Johan. After Violence: 3R, Reconstruction, Reconciliation, Resolution: Coping With Visible and Invisible Effects of War and Violence.

91 - Curle, Adam. Another Way: Positive Response to Contemporary Violence. Oxford: Jon Carpenter Pulflishing, April 1, 1996.

92 - Gad Barzilai.(2003). Communities and Law: Politics and Cultures of Legal Identities. Ann Arbor: University of Michigan Press. 